\title{
A Review of Bioactive Factors in Human Breastmilk: A Focus on Prematurity
}

\author{
Andrea Gila-Diaz ${ }^{1}$, Silvia M. Arribas ${ }^{1}$, Alba Algara ${ }^{1}$, María A. Martín-Cabrejas ${ }^{2}$, \\ Ángel Luis López de Pablo ${ }^{1}$, Miguel Sáenz de Pipaón ${ }^{3,4}$ and David Ramiro-Cortijo ${ }^{1, * \mathbb{C}}$ \\ 1 Department of Physiology, Faculty of Medicine, Universidad Autónoma de Madrid, 28029 Madrid, Spain; \\ andrea.gila@estudiante.uam.es (A.G.-D.); silvia.arribas@uam.es (S.M.A.); \\ alba.algara@estudiante.uam.es (A.A.); angel.lopezdepablo@uam.es (Á.L.L.d.P.) \\ 2 Department of Agricultural Chemistry and Food Science, Universidad Autónoma de Madrid, \\ Institute of Food Science Research, CIAL (UAM-CSIC), 28049 Madrid, Spain; maria.martin@uam.es \\ 3 Neonatology Service, La Paz Hospital-Universidad Autónoma de Madrid, 28046 Madrid, Spain; \\ miguel.saenz@salud.madrid.org \\ 4 Carlos III Health Institute, Maternal and Child Health and Development Research Network, \\ 28029 Madrid, Spain \\ * Correspondence: david.ramiro@uam.es; Tel.: +34-914-975-416
}

Received: 10 April 2019; Accepted: 4 June 2019; Published: 10 June 2019

\begin{abstract}
Preterm birth is an increasing worldwide problem. Prematurity is the second most common cause of death in children under 5 years of age. It is associated with a higher risk of several pathologies in the perinatal period and adulthood. Maternal milk, a complex fluid with several bioactive factors, is the best option for the newborn. Its dynamic composition is influenced by diverse factors such as maternal age, lactation period, and health status. The aim of the present review is to summarize the current knowledge regarding some bioactive factors present in breastmilk, namely antioxidants, growth factors, adipokines, and cytokines, paying specific attention to prematurity. The revised literature reveals that the highest levels of these bioactive factors are found in the colostrum and they decrease along the lactation period; bioactive factors are found in higher levels in preterm as compared to full-term milk, they are lacking in formula milk, and decreased in donated milk. However, there are still some gaps and inconclusive data, and further research in this field is needed. Given the fact that many preterm mothers are unable to complete breastfeeding, new information could be important to develop infant supplements that best match preterm human milk.
\end{abstract}

Keywords: adipokines; antioxidants; breastfeeding; cytokines; growth factors

\section{Introduction}

Preterm infants are those born before 37 weeks of gestation [1]. They are considered extremely preterm at less than 28 weeks, very preterm between 28 and 32 weeks, and moderate to late preterm between 32 and 37 weeks [2].

Prematurity is a serious health problem worldwide, with increasing rates in both low- and high-income countries [2,3]. The World Health Organization (WHO) estimated that the global incidence of preterm delivery was around $11.1 \%$ in 2010. The frequency of preterm births (PTBs) in low-income settings is between $12 \%$ and $18.1 \%$ [2], with Asia and Africa being the areas with the highest rates [4]. The frequency of PTB can vary between 5\% and 13\% in high-income areas such as the United States of America [5].

PTB is a multifactorial syndrome and has multiple etiologies. The main factors that may increase women's risk are maternal malnutrition, poor pregnancy weight gain, infections and maternity at 
extreme ages, short interpregnancy intervals, or/and obstetric complications. Infertility and the subsequent need for assisted reproduction techniques resulting in twin pregnancies are also important factors. Finally, exposure to lifestyle-related toxic substances and environmental pollutants are also considered as potential risk factors [3-8].

Preterm infants, in comparison with term infants, have higher morbimortality rates. Throughout the world, prematurity is the second most common cause of death among children under 5, and is the leading cause in high-income countries [4,9]. Late onset sepsis [10], necrotizing enterocolitis (NEC) [11], retinopathy of prematurity (ROP) [12], bronchopulmonary dysplasia (BPD) [13], and neurodevelopmental problems [14] are among the most frequent morbidities. Besides, growing evidence is proving that individuals born preterm are at higher risk of cardiovascular and metabolic diseases in adulthood [15-17].

Nutrition during the earliest stage of life is of great importance for the growth and maturation of tissues and organs, especially for those infants with PTB. Breastmilk (BM) is tailored to cover the needs of the newborns, providing the adequate amount of macro and micronutrients for infant growth and development. In addition, it contains several bioactive compounds, which contribute to the maturation of their immune system, among other important aspects. The BM composition is dynamic and varies according to the maternal age, number of pregnancies [18], body mass index (BMI) [19], maternal diet, time of the day, lactation period, and other environmental factors [20]. Therefore, the WHO recommends that infants be exclusively breastfed for the first six month of life, and lactation, together with nutritionally adequate foods, can continue up to two years of age or beyond [21,22]. This recommendation has been endorsed by several Pediatric and Nutrition Associations [23-25].

Among the most important bioactive compounds found in BM, the most outstanding are antioxidants, which may help counteracting the negative effects of oxidative stress in newborns [26]. Other bioactive compounds to bear in mind are growth factors and hormones, which regulate the energy intake and maturation of organs. Also, cytokines are present in BM, which may help to protect against infections or reduce inflammatory processes [20]. These bioactive compounds may contribute to the long-term protection of preterm infants against the development of cardiometabolic diseases. Premature infants fed with BM exhibit lower rates of metabolic syndrome, hypertension, or insulin resistance in adolescence, compared with the newborns who are not breastfed [24,27].

$\mathrm{BM}$ is the ideal food for neonates during the first days of life and cannot be equaled by artificial substitutes [28]. However, there are mothers who, for several reasons, do not breastfeed their newborns. In 2018, 7.6 million babies were not breastfed [29]. In these cases, commercial formulas and donated $\mathrm{BM}$, generally from mothers with term deliveries [30], are used. The human milk is recognized as a better scavenger of free radicals than the infant formula due to its bioactive compounds, which are lacking in commercial formulas [31,32].

The aim of this review is to summarize the role of some bioactive factors present in BM, namely antioxidants, growth factors, adipokines, and cytokines, with specific attention to the differences between preterm and full-term human milk; we also summarize their role on the development and the potential beneficial actions on neonatal and long-term health of premature infants.

\section{Bioactive Compounds in Breastmilk}

There is wide evidence that BM prevents many of the perinatal complications associated with preterm labor [33], and BM is recognized as a protective factor against morbidity and mortality. Some of the beneficial factors against preterm complications may be related to the bioactive compounds and interactive elements present in the milk, such as antioxidants, growth factors, adipokines, cytokines, or antimicrobial compounds [34].

\subsection{Antioxidants in Human Milk}

Reactive oxygen species (ROS) are physiologically relevant molecules that participate in cellular signaling processes. However, ROS are highly oxidizing and, in excess, can cause damage to cellular 
structures. To counteract the oxidative effects of ROS, there are a wide variety of antioxidant systems. There is a delicate balance between ROS and other reactive species and antioxidants. If this balance is lost, the result is oxidative stress. This can be due to an excessive ROS production that exceeds the antioxidant capacity, or insufficient antioxidant systems.

Birth represents a significant oxidative challenge because of the switch from the relatively low-oxygen intrauterine environment to the high-oxygen extrauterine atmosphere [35]. Thus, newborns are exposed to an increase in ROS during labor and the transition to neonatal life [36]. PTB disrupts the normal developmental upregulation of antioxidant systems. Increased oxidative stress is observed in preterm neonates compared with full-term infants [37], being a critical factor that exacerbates perinatal morbidities of prematurity [38].

Endogenous antioxidants can be classified as enzymatic (i.e., superoxide dismutase (SOD), catalase, or glutathione peroxidase (GPx)), small non-enzymatic molecules (like glutathione (GSH)), or hormones with antioxidant capacity (such as melatonin) [37,39]. In addition to endogenous antioxidants, several foods, mainly vegetables and fruits, contain antioxidants such as vitamins, carotenoids, and polyphenols, among others.

\subsubsection{Antioxidant Properties of Breastmilk}

BM has a powerful antioxidant composition and all the above-mentioned compounds have been found in it $[18,19,26,40,41]$. Antioxidants are important for newborn protection against disease [28], and may be critical for infants with PTB. There is evidence that premature neonates nourished with BM have less oxidative stress, evidenced by the lower levels of oxidative damage biomarkers compared with the infants who were formula fed [40,42]. It has been proposed that the reduction in oxidative damage by BM may be related to the reduction in ROS synthesis—evidenced for hydroxyl radicals—or to an increase in the antioxidant defense systems [42]. Some reports show that preterm infants fed with BM plus a fortifier had higher antioxidant urinary levels compared to both infants exclusively fed $\mathrm{BM}$ and with those who were formula-fed; the mechanisms remain unclear [43] and this aspect should be further analyzed.

The total antioxidant capacity of BM seems to be higher in colostrum compared to mature milk $[44,45]$ and its radical scavenging activity decreases along the lactation period. Pasteurization processes and storage conditions of BM may reduce antioxidants [46], as well as some immunological and nutritional properties. For example, refrigeration decreases the concentration of vitamins, lactoferrin, and lipases. Therefore, it is not recommended for BM. However, despite the fact that these treatments alter the bioactive compounds, donated milk should be pasteurized and frozen. As stated by the Spanish Association of Pediatrics, the development of methods to improve the preservation of the antioxidant capacity of donated $\mathrm{BM}$, or any factors improving maternal antioxidant status, deserve further investigation [47]. BM treatment is important, particularly in the context of prematurity. Certain viruses, such as cytomegalovirus, may infect the newborn [48] through raw BM transmission [49]. The cytomegalovirus infection is problematic in preterm infants, particularly in those with very low birth weight [48].

Differences in antioxidant capacity of term and preterm BM remain controversial. Some data show that preterm BM has more antioxidants and equal resistance to oxidative stress as compared to term human milk [43]. On the other hand, other studies show a lower total antioxidant capacity in preterm BM compared to full-term BM [44,50]. It has been suggested that this is due to the fact that antioxidants tend to accumulate over the last three months of gestation. Thus, it is proposed that a mother with a PTB would synthetize a less antioxidants [50,51]. Discrepancies in the antioxidant activity between term and preterm BM may be related to differences in the ethnic group studied or the maternal nutritional habits. Another possible explanation to this controversy could be the time point when the studies were conducted. In this sense, it has been observed that the total antioxidant capacity of premature BM does not decline after one week, and preterm neonates benefit more from the antioxidant capacity of colostrum and transitional milk [50]. Term milk may differ in this respect. 
Taken together, these reports suggest that more research is needed in this area. Aspects such as ethnicity, maternal nutritional status, or breastfeeding period should be taken into account in future studies to clarify differences in antioxidant properties in BM and its relationship with infant needs.

\subsubsection{Antioxidants Present in Breastmilk}

The antioxidant properties of human BM are related to the combination of different compounds, both exogenous and endogenous molecules.

Several food-derived antioxidants, including polyphenols, carotenoids, and vitamins, have been reported in BM, and there is evidence that they are more abundant in preterm than in full-term BM. The levels of these bioactive components also differ in formula milk. As stated in Table 1, the levels of antioxidants included in formula milk do not always match the reports in BM, and in some instances are clearly much higher. An excess in antioxidants may be deleterious, since some antioxidants may turn into pro-oxidant molecules under certain circumstances. Therefore, research on the adequate requirements of antioxidants in both term and preterm infants and adjustment of the antioxidant content in formula are needed.

Table 1. Exogenous antioxidants in breastmilk.

\begin{tabular}{ccccc}
\hline $\begin{array}{l}\text { Antioxidant } \\
\text { Compounds }\end{array}$ & Preterm Infants & \multirow{2}{*}{ Term Infants } & \multicolumn{2}{c}{ Formula Feeding } \\
\cline { 4 - 5 } & & & Preterm & Term \\
\hline$\alpha$-carotene & 7.7 & 3.6 & 0.51 & 1.40 \\
$\beta$-carotene & 49.1 & 13.7 & 71.1 & 63.9 \\
Lycopene & 66.1 & 11.9 & 1.5 & 5.8 \\
Retinol & 401.6 & 185.8 & 3086.2 & 911.8 \\
$\alpha$-tocopherol & 5880.8 & 622.8 & $20,109.1$ & $13,360.2$ \\
$\gamma$-tocopherol & 1207.1 & 6787.1 & 6561.6 \\
\hline
\end{tabular}

Adapted from Hanson et al. (2016) [31]. The data are expressed as $\mu \mathrm{g} / \mathrm{L}$.

Enzymatic antioxidants are also important to counteract oxidative processes. The main enzymatic systems which detoxify ROS are SOD, catalase, and GPx. SOD catalyzes the dismutation of superoxide anion to hydrogen peroxide, which must be removed by catalase. Three SOD isoforms (copper-zinc, manganese, and extracellular SOD) are present in mammals, with different subcellular locations and tissue distribution [52]. Catalase consists of four protein subunits, which make it very resistant to $\mathrm{pH}$ changes, thermal denaturation and proteolysis [53]. This enzyme eliminates the hydrogen peroxide generated by SOD and completes the reaction to eliminate ROS [52]. Finally, GPx participates, together with catalase, in the detoxification of hydrogen peroxide among other organic hydroperoxides [54,55].

There is evidence of some of these enzymatic systems and their concentrations have been reported. Catalase has been found in human BM, with some differences between term and preterm BM [19]. In milk from term mothers, the catalase concentration ranges between 0.43 and $0.84 \mathrm{U} / \mathrm{mg}$ protein, and in preterm BM the concentration has been found to be $0.5-0.97 \mathrm{U} / \mathrm{mg}$ protein [40]. GPx has also been found in BM, with a maximum value of $31.2 \mathrm{mM} / \mathrm{min} / \mathrm{L}$ [56].

Regarding non-enzymatic systems, GSH is a three amino acid peptide, which is the main intracellular low molecular weight antioxidant. It participates in the regeneration of other antioxidants, such as vitamin $\mathrm{C}$ and $\mathrm{E}$ to their active forms $[57,58]$. GSH has been found in BM in concentrations ranging from 10.4 to $43.1 \mathrm{nmol} / \mathrm{mg}$.

Melatonin is the major endocrine product of the pineal gland, which plays a physiological role in neuroimmunomodulation. It is synthetized from tryptophan via serotonin in pinealocytes and many other cells, with a circadian regulation [59-64]. Melatonin is interesting in the context of BM bioactive compounds due to its pleiotropic actions. It has been demonstrated to exhibit protective effects against cellular aging due to its antioxidant effects, both as a direct scavenger, and stimulating the expression of SOD, catalase, and GPx [60,65-68]. On the other hand, melatonin appears to be one of the most 
promising molecules for neuroprotection in preterm infants due to its effects on the modulation of neuroinflammatory pathways [69].

Melatonin is present in BM in much higher concentrations during night time, being almost undetectable during the day. So far, the studies have not been able to detect differences between preterm and term BM mothers. Some studies have observed higher levels in colostrum, which has been reported to increase the phagocytic activity of cells against bacteria. A longer sleep time was observed in newborns who were breastfed than in those who were formula-fed [70]. Table 2 describes several endogenous antioxidants and their concentrations in BM.

Table 2. Endogenous antioxidants in breastmilk.

\begin{tabular}{ccc}
\hline Antioxidant & Activity & Range \\
\hline Superoxide dismutase & Eliminates superoxide anion & $2.01-6.26 \mathrm{nmol} / \mathrm{min} / \mathrm{mL}$ \\
\hline Catalase & Eliminates hydrogen peroxide & $1.84-26.1 \mathrm{nmol} / \mathrm{min} / \mathrm{mL}$ \\
\hline Glutathione peroxidase & Eliminates hydrogen peroxide & $6.6-17.7 \mathrm{mM} / \mathrm{min} / \mathrm{L}$ \\
\hline Glutathione & Regeneration of other antioxidants & $10.4-43.1 \mathrm{nmol} / \mathrm{mg}$ of protein \\
\hline Melatonin & Free radical scavenger, antioxidant & $<10-23 \mathrm{ng} / \mathrm{L}$ \\
\hline
\end{tabular}

Adapted from $[18,26,41,54-57,60-64,66]$.

\subsection{Growth Factors in Human Milk}

Preterm infants are immature neonates who usually exhibit growth retardation, poor development and physical and neurological deficits. Postnatal growth retardation is likely the result of inadequate nutrition support after delivery, also contributing to poor neonatal health. In this context, in addition to a macronutrient supply, growth factors provided by breastfeeding may be of great importance. Growth factors play a role in the growth, maturation, and integrity of several organs, particularly for the neonatal gastrointestinal tract [71]. They help with the maturation of gut immunity and have anti-inflammatory effects [72,73]. Hirai et al. described the trophic effects of growth factors on fetal and neonatal gastrointestinal tract by promoting the proliferation and differentiation on their immature cells [74]. The highest concentrations of growth factors are provided by colostrum, as the first milk released after birth [75].

The main growth factors present in BM and their trophic effects on neonatal organs and systems are summarized in Figure 1.

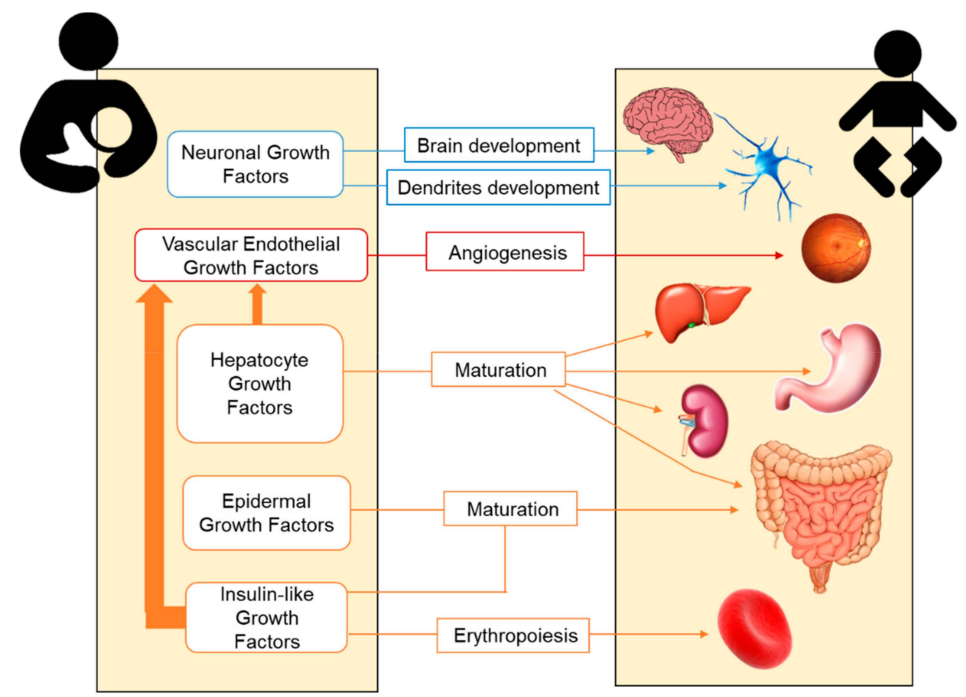

Figure 1. Transference of maternal growth factors through breastmilk and their trophic effects on the growth and maturation of neonatal organs and systems. 


\subsubsection{Hepatocyte Growth Factor (HGF)}

HGF was first identified as a potent mitogen of primary cultured hepatocytes. The essential role is promoting organogenesis. It is also involved in the formation of the kidney, lung, mammary gland, teeth, muscle, and neuronal tissues [76]. To preserve proliferation, angiogenesis, and intestinal tissue development through paracrine and endocrine signaling, high levels of HGF are required in BM. This factor is released into BM by multipotent mesenchymal stem cells [77]. In addition to direct proliferative properties, HGF may also regulate the vascular endothelial growth factor (VEGF) synthesis [78].

\subsubsection{Epidermal Growth Factor (EGF)}

EGF is recognized as a critical trophic factor for the normal intestinal cell development (Table 3). The members of the EGF family are first synthetized as transmembrane precursors, eventually undergoing proteolysis into the mature, secreted form of the growth factor [71].

Both the amniotic fluid and the BM contain EGF [79,80]. A member of the EGF family is the heparin-binding growth factor (HB-EGF). Its exogenous administration protects from intestinal ischemia-reperfusion injury, hemorrhagic shock, and NEC by enhancing the healing of intestinal anastomoses and reducing anastomotic complications [81,82]. In BM, EGF levels are higher at the beginning of the lactation period and decrease over time. Furthermore, preterm BM contains higher levels of EGF than term BM, which may help in the reduction of NEC incidence [83]. However, very preterm BM contains lower levels than preterm milk, although still higher compared to term milk. In preterm colostrum EGF content has been found in the range of $22.8-373 \mu \mathrm{g} / \mathrm{L}$ and in term colostrum between 27.7 and $209 \mu \mathrm{g} / \mathrm{L}$ [84].

\subsubsection{Neuronal Growth Factors}

Brain-derived neurotrophic factor (BDNF) is a small neurotrophic protein, which is widely expressed in the mammalian adult brain $[85,86]$. BDNF, together with S100B protein and glial cell line-derived neurotrophic factor (GDNF), plays a critical role in the development and maintenance of the nervous system, and in neuronal survival and proliferation [87]. BDNF, S100B, and GDNF are present in human milk. S100B protein and GDNF levels increase within the lactation period [86].

\subsubsection{Insulin-Like Growth Factor (IGF) Superfamily}

Human BM contains IGFs such as IGF-I and IGF-II [88]. IGF-I synthesis is regulated by the availability of amino acids and the overall energy intake, and is a marker of the nutritional status. IGF-I levels in BM are higher during the first days after delivery, decreasing as the milk matures [89]. No significant differences were found between preterm and term milk in other growth factors from this family, except for IGF-I and IGF-II, which is higher in preterm milk [88,90]. IGF-I could be important in the protection of enterocytes after intestinal damage caused by ROS [91]. Enteral IGF-I administration enhances erythropoiesis and augments hematocrit, but its function is still not clearly known [20].

\subsubsection{Vascular Endothelial Growth Factor (VEGF)}

VEGF mediates vascularization, which is also controlled by IGF-I. In preterm infants, the relative hyperoxia found in the extrauterine environment inhibits the expression of VEGF, interrupting the growth of retinal blood vessels. Pulmonary immaturity and the subsequent need for oxygen therapy contribute to the susceptibility of the retinal tissue to the oxidative injury and the subsequent development of ROP [92].

VEGF levels in BM are higher at the beginning of the lactation period, which helps reducing ROP's burden during the first days of life. There are some controversies regarding the differences in this growth factor between preterm and term BM. While no differences have been reported in some 
studies [93], other authors demonstrate both lower and higher levels of VEGF in preterm compared to full-term milk (Table 3) [73,90].

\subsubsection{CD14 Protein}

CD14 acts as a co-receptor for the detection of bacterial lipopolysaccharide (LPS) [94]. CD14 is a protein with two forms: one is a soluble form (sCD14) and the other is anchored to the cellular membrane (mCD14). This latter membrane-bound form is primarily expressed on the surface of monocytes, macrophages and neutrophils $[95,96]$. CD14 may have a major implication due to the protection provided against subsequent allergy manifestations [97]. There is some evidence that low levels of sCD14 in BM are associated with eczema development [98]. In addition, other factors such as the newborn genotype and the interaction with the bioactive factor present in BM may also participate in the development of allergies [96].

Table 3. Growth factors in breastmilk.

\begin{tabular}{cccc}
\hline Growth Factors & $\begin{array}{c}\text { Main Tissue } \\
\text { Synthesized }\end{array}$ & $\begin{array}{c}\text { Range } \\
(\mu \mathrm{g} / \mathrm{mL})\end{array}$ & Main Neonatal Functions \\
\hline Epidermal-GF & $\begin{array}{c}\text { Submandibular } \\
\text { salivary gland }\end{array}$ & $24-37$ & $\begin{array}{c}\text { Intestinal mucosa maturation and healing, } \\
\text { nutrient absorption, protein synthesis }\end{array}$ \\
\hline Neuronal-GF & $\begin{array}{c}\text { Cerebral cortex and } \\
\text { hippocampus }\end{array}$ & $2.8-934$ & $\begin{array}{c}\text { Nervous system maturation, learning, } \\
\text { and memory }\end{array}$ \\
\hline Insulin-like-GF & $\begin{array}{c}\text { Placenta and } \\
\text { digestive system }\end{array}$ & $5-35$ & Retinal vascularization, brain maturation \\
\hline Vascular Endothelial-GF & Adapted from [20,71,80,85-87,90,99]; GF, growth factors & Angiogenesis \\
\hline
\end{tabular}

\subsection{Adipokines in Human Milk}

In addition to growth factors, adipokines constitute another group of compounds present in $\mathrm{BM}$ which is important for metabolism and infant growth. These cytokines derived from adipocytes have been demonstrated to modify weight gain and fat and lean body mass in infants in the early postpartum period [100] and have long-term effects on metabolic programming. They are also involved in the regulation of food intake and energy balance [101]. Several adipokines, with opposing actions on food intake and energy expenditure, have been found in BM (summarized in Table 4). Thus, it can be hypothesized that the programming of food intake and body composition may be influenced by the relative concentration of these compounds in BM. Likewise, BM adipokines may also modulate the development of metabolic diseases in adulthood such as obesity, type 2 diabetes mellitus, or insulin resistance [102].

\subsubsection{Leptin}

Leptin is an anorexigenic hormone encoded in the ob gene and mostly synthesized by white adipose tissue, which acts through the arcuate nucleus of the hypothalamus. Leptin minimizes the energy intake and increases the energy expenditure [101], and it plays a role in fetal and neonatal growth $[103,104]$.

Several studies have reported the presence of leptin in BM, which may be produced by various cell types in the mammary tissue. The ob gene is expressed in the epithelium of the mammary gland of lactating women and it produces leptin [105]. Leptin is also transported from maternal circulation to BM [106] and it has been reported that plasma and BM levels are directly associated with the fat content and the body mass index [100,107]

Leptin levels in human milk vary over the lactation period [108]. Differences in BM leptin concentrations are also reported comparing whole and skimmed milk. In mothers with term infants, 
leptin concentration in whole milk ranged between 0.2 to $10.1 \mathrm{ng} / \mathrm{mL}[109,110]$, being lower in skimmed milk at between 0.1 to $3.4 \mathrm{ng} / \mathrm{mL}$ [111,112]. Leptin levels seem to be higher in BM from mothers with preterm newborns, with concentrations ranging between 0.6 and $5.3 \mathrm{ng} / \mathrm{mL}$ in skimmed milk [108,113].

Table 4. Adipokines in human breastmilk.

\begin{tabular}{|c|c|c|c|c|}
\hline Adipokines & Tissue Synthesized & $\begin{array}{l}\text { Range } \\
(\mathrm{ng} / \mathrm{mL})\end{array}$ & $\begin{array}{l}\text { Preterm } \\
\text { Infants }\end{array}$ & Main Neonatal Functions \\
\hline Leptin & $\begin{array}{l}\text { White adipose } \\
\text { Placenta } \\
\text { Mammary }\end{array}$ & $0.2-10.1$ & $\uparrow / ?$ & $\begin{array}{c}\text { Anorexigenic } \\
\text { T-lymphocyte responses }\end{array}$ \\
\hline Adiponectin & Adipocytes & $4.2-87.9$ & $\approx / ?$ & $\begin{array}{c}\text { Orexigenic } \\
\text { Regulation of lipid/glucose metabolism } \\
\text { Improvement of insulin sensitivity } \\
\text { Anti-inflammatory actions }\end{array}$ \\
\hline Resistin & $\begin{array}{l}\text { Immune cells } \\
\text { Epithelial cells }\end{array}$ & $0.2-1.8$ & $\uparrow / ?$ & $\begin{array}{l}\text { Regulation of glucose homeostasis } \\
\text { Inhibition of adipocyte differentiation } \\
\text { Inflammatory response }\end{array}$ \\
\hline Ghrelin & $\begin{array}{l}\text { Stomach } \\
\text { Pituitary } \\
\text { Other }\end{array}$ & $0.07-6$ & $?$ & $\begin{array}{c}\text { Orexigenic } \\
\text { Gastric motility and secretion } \\
\text { Adipogenesis } \\
\text { Anti-inflammatory actions }\end{array}$ \\
\hline Obestatin & $\begin{array}{c}\text { Stomach } \\
\text { Small intestine }\end{array}$ & $0.4-1.3$ & $?$ & $\begin{array}{c}\text { Anorexigenic } \\
\text { Body weight regulation }\end{array}$ \\
\hline Nesfatin & $\begin{array}{l}\text { Neurons } \\
\text { Pancreas } \\
\text { Other }\end{array}$ & $0.008-0.01$ & $?$ & $\begin{array}{c}\text { Anorexigenic } \\
\text { Production of body fat }\end{array}$ \\
\hline Apelin & $\begin{array}{l}\text { Heart } \\
\text { Lung } \\
\text { Other }\end{array}$ & $43-81$ & $?$ & $\begin{array}{c}\text { Regulation of cardiovascular system } \\
\text { Fluid homeostasis } \\
\text { Angiogenesis } \\
\text { Regulation of insulin secretion }\end{array}$ \\
\hline
\end{tabular}

Adapted from Catli et al. (2014) [102]. Arrows indicate the comparison with term infants ( $\uparrow$, higher; $\downarrow$, lower; $\approx$, similar); ? indicates unavailable or inconclusive data and the need for research.

Several reports indicate that leptin levels in BM can play an important role in infant growth, and its production by human mammary epithelial cells might be regulated physiologically according to the necessity and the state of the infant [114]. Maternal milk of small, appropriate, and large gestational age infants (SGA, AGA, and LGA) has different leptin levels, especially during the first month of life. Human milk leptin levels are significantly reduced in the SGA neonates compared to AGA and LGA infants, together with a rapid growth during the first postnatal 15 days. It has also been reported that leptin levels in milk of infants with accelerated postnatal growth were lower than in infants with normal growth [115]. These findings suggest that the presence of leptin in BM might play an important role in growth, appetite and regulation of nutrition in infancy, especially during the early lactation period.

\subsubsection{Adiponectin}

Adiponectin is an orexigenic hormone which regulates lipid and glucose metabolism. Adiponectin enhances insulin sensitivity and stimulates fatty acid oxidation through the activation of AMP-activated protein kinase (AMPK) in peripheral tissues, and inhibits hepatic glucose production [101]. In addition, adiponectin has powerful anti-inflammatory effects, influencing the vascular endothelium. Adiponectin stimulates the food intake through the hypothalamus and reduces the energy expenditure through its central activity [116]. The production of adiponectin is regulated by the peroxisomal 
proliferator-activated receptor- $\gamma$ (PPAR- $\gamma)$, a nuclear receptor expressed in the liver and muscle, which protects against obesity-related insulin resistance [117].

Adiponectin is present in $\mathrm{BM}$, in a range between 4.2 and $87.9 \mathrm{ng} / \mathrm{mL}$ [118], being more than 40 times greater than the concentrations of leptin [119]. In the colostrum higher levels have been reported, with concentrations in the range between 2.9 and $317 \mathrm{ng} / \mathrm{mL}$ [118], in accordance with studies showing that BM adiponectin levels are negatively associated with the lactation period [120]. Other factors that may influence BM adiponectin levels are the maternal nutritional status and body composition, although this aspect is still controversial. Some studies report a positive association between adiponectin and maternal body fat mass [120]; others demonstrate that the adiponectin concentration in colostrum is markedly dependent on maternal diet and nutritional status during pregnancy, and there are also reports that failed to observe an association with maternal BMI or infant birth weight [121]. The maternal hormonal and inflammatory profile may also alter the BM adiponectin levels [122].

$\mathrm{BM}$ adiponectin also seems to have an influence on infant growth. In term infants who were breastfed for at least six months, high levels of adiponectin are associated with overweight [123]. These data support that BM adiponectin in the first stages of life could have an important implication in the regulation of infant growth [124], which deserves further consideration.

\subsubsection{Resistin}

Resistin is an adipocyte-derived hormone, which regulates glucose homeostasis and counteracts the action of insulin in peripheral tissues, inhibits adipocyte differentiation and may function as a regulator of adipogenesis [101]. Resistin has been identified in BM in a range between 0.2 and $1.8 \mathrm{ng} / \mathrm{mL}$ [125] and its levels decrease along the lactation period [126]. In the perinatal period, it seems that resistin is not directly involved in the regulation of insulin sensitivity or adipogenesis [127]. It has been suggested that resistin could have a role in controlling fetal growth together with other BM hormones, and could be involved in the appetite regulation and in the metabolic development of infants [104]. Resistin could also have an important role in the regulation of the energy metabolism and adiposity in utero. Higher serum resistin levels have been found in term infants compared to preterm infants [102], and it has been suggested that newborns could benefit from these higher concentrations of circulating resistin, facilitating the production of hepatic glucose and preventing hypoglycemia after delivery [128].

\subsubsection{Ghrelin}

Ghrelin is an amino acid synthesized in several organs from the digestive and nervous system, heart and lungs, the stomach being the main site of production [129]. It is one of the most important orexigenic peptides. However, in addition to the functions related to the regulation of food intake and metabolism, ghrelin has other physiological actions, such as in gastric motility and acid secretion, reduction of insulin secretion, adipogenesis, and cardiovascular function, as well as anti-inflammatory effects. Ghrelin secretion declines in situations of positive energy balance, such as after food intake or in obesity, while increasing when fasting or during weight loss.

The presence of ghrelin in BM may be a strong factor influencing the feeding behavior, and body composition later in life, through its effects on short-term food intake and long-term body weight [104]. Ghrelin is found in both term and preterm human BM [130], with concentrations in the range of 73-6000 pg/mL [131,132]. A gradual and parallel increase has been observed between post-partum ghrelin plasma levels and the concentration in BM [130]. However, this physiological increase is impaired in women with gestational diabetes and pre-gestational diabetes mellitus [133]. These alterations may alter the infant's feeding behavior.

A positive correlation between ghrelin concentrations in mature BM and infant weight gain has been found, suggesting that this hormone is involved in postnatal growth [134]. Savino et al observed that infants who were fed with formula milk had higher serum ghrelin levels than those who were 
breastfed. They propose that formula-fed infants have a better feeding stimulus, which makes them eat more, and consequently, boosts their growth and weight gain. This can explain the protective effect of BM against the development of obesity in childhood and adulthood [135].

\subsubsection{Obestatin}

Obestatin drifts from ghrelin and its synthesis is mainly produced by digestive system cells, especially from the stomach and small intestine [136]. Obestatin is an anorexigenic hormone which reduces food intake, regulates weight gain and gastric emptying by suppressing the intestinal motility [125]. It was proposed that, in addition to its effects on energy balance regulation, it opposes the actions of ghrelin [130]. Some data have identified higher levels of obestatin in BM than in maternal blood [130]. The reported range of obestatin in BM is from 0.4 to $1.3 \mathrm{ng} / \mathrm{mL}$ [125]. Although it is not completely confirmed, some authors have suggested that colostrum have higher levels of obestatin to prepare the digestive system to receive milk by reducing newborn appetite. [130].

\subsubsection{Nesfatin}

Nesfatin is an anorexigenic [93] neuropeptide related to the melanocortin signaling pathway in the hypothalamus. It is mainly manifested in nervous system cells and peripheral tissues. Nesfatin acts as an appetite regulator and a body fat producer. [137]. Nesfatin has been found in BM in a range between 8 and $14 \mathrm{pg} / \mathrm{mL}$ [138].

\subsubsection{Apelin}

Apelin, an endogenous ligand for the G-protein-receptors [139], participates by maintaining the cardiovascular and fluid homeostasis, regulates appetite, cell proliferation and angiogenesis [140]. Although apelin has been found to regulate food intake, most of the studies have been made on rats, and the results are controversial. More studies in humans are needed to clarify its effect on food intake [140-143]. Apelin concentrations in BM have been ranged between 43 and $81 \mathrm{pg} / \mathrm{mL}$, being lower in women who developed gestational diabetes [133].

\subsection{Cytokines in Human Milk}

Cytokines are small proteins synthesized by nearly all the nucleated cells [144]. They are signaling molecules involved in the communication between cells [82]. BM is a cytokine-rich food [145]. According to their role in the inflammatory response, cytokines can be divided into those that promote inflammation or protects against infection, and those that decrease inflammation.

A possible role of some cytokines present in BM in preterm infants may be to compensate the delay of the immune system development [146]. It has been hypothesized that immune mediators in human milk may have a powerful role to play in maturating the infant intestine and stimulating the immune system [97]. The stimulation of immune activity by BM cytokines may be related to their capacity to make connections with cells by crossing the intestinal barrier.

There is large variability between cytokine concentrations among breastfeeding women, being pro-inflammatory cytokines generally low [147]. BM cytokine content can be affected by different factors, such as gestational age, maternal diet, infections, smoking, maternal ethnicity, or exercise [147]. In addition, the cytokine profile of BM fluctuates along the different phases of breastfeeding and the clinical significance of cytokine concentrations in neonatal health outcomes is still under debate $[148,149]$.

\subsubsection{Anti-Inflammatory Cytokines in Human Breastmilk}

The anti-inflammatory cytokines found in BM include transforming growth factor- $\beta$ (TGF- $\beta$ ), interleukin 7 (IL-7), and IL-10 (Figure 2). IL-7 BM is known to cross the intestinal barrier and contribute to thymus and T-lymphocyte development [150]. In colostrum, IL-10 ranges from 5.9 to $7.3 \mathrm{ng} / \mathrm{L}$ in 
term and from 1.1 to $8.8 \mathrm{ng} / \mathrm{L}$ in preterm infants. It has also been reported that these concentrations decrease over lactation, with an average of 0.7 to $1.3 \mathrm{ng} / \mathrm{L}$ and 0.5 to $0.9 \mathrm{ng} / \mathrm{L}$ for term or preterm mature milk, respectively [81]. The possible differences in IL-10 concentrations between preterm and term milk are still controversial. While some authors have reported lower levels in preterm milk [151], others fail to demonstrate significant differences [152]. An interesting aspect is the finding of a lower IL-10 in BM of infants with increased risk of NEC [153]. These results suggest that the accessibility of this cytokine from BM may be important to modulate the neonatal inflammatory response; however, this is an aspect which deserves further research.

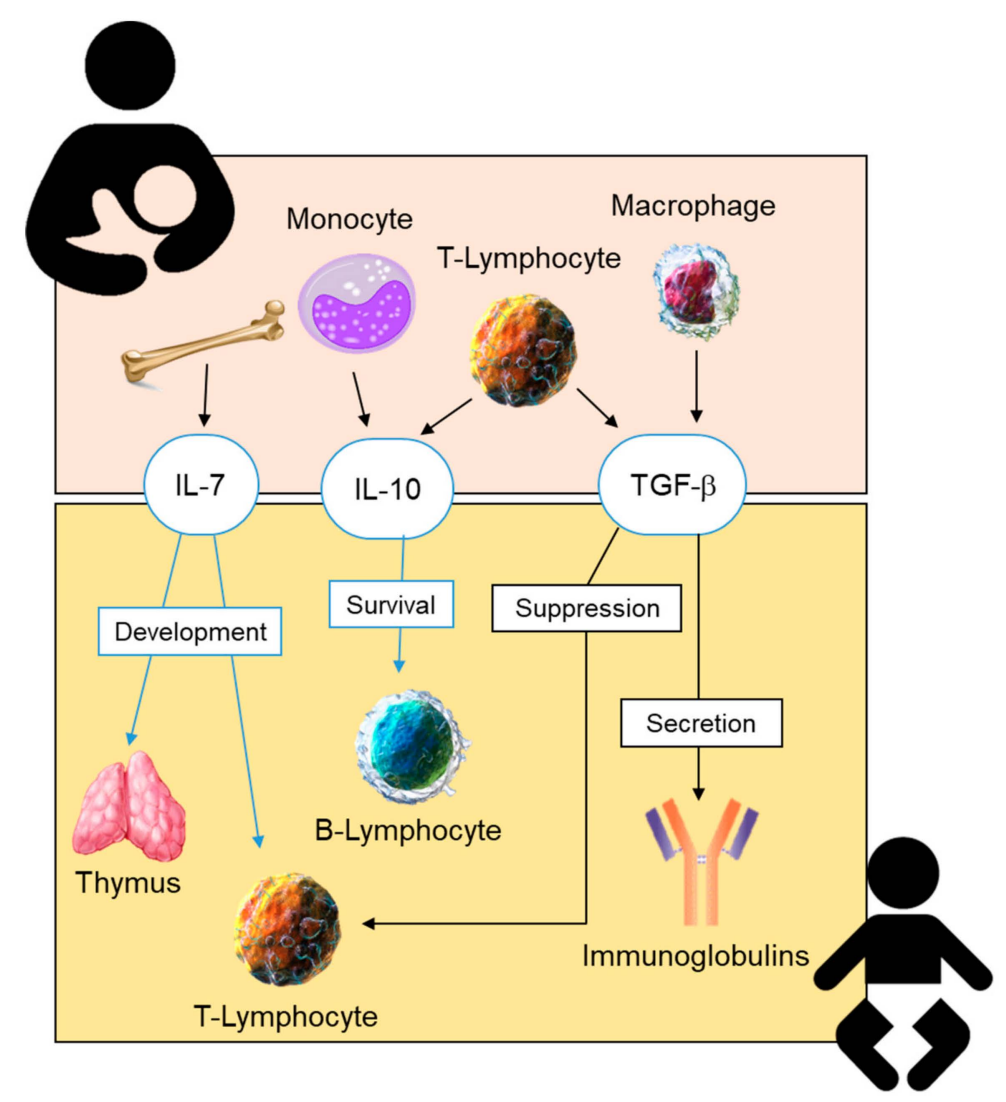

Figure 2. Site of synthesis of anti-inflammatory cytokines present in human breastmilk, and their effects on the neonatal immune system. IL-6, interleukin-6; IL-10, interleukin-10; TGF- $\beta$, transforming growth factor- $\beta$.

Transforming Growth Factor- $\beta$ (TGF- $\beta$ )

TGF- $\beta$ is an anti-inflammatory cytokine mainly produced by parenchymal cells and infiltrating cells such as lymphocytes, macrophages and platelets [154]. It is found in human milk, with higher levels in colostrum. During breastfeeding, all three isoforms of the TGF- $\beta$ superfamily are produced, the majority being TGF- $\beta 2$ [75]. The levels of this cytokine range between 0.1 and $13.3 \mu \mathrm{g} / \mathrm{L}$ in term colostrum and between 1.4 and $43 \mu \mathrm{g} / \mathrm{L}$ in preterm colostrum. These levels decrease along the lactation period, with concentrations in the order of $0.4-2.8 \mu \mathrm{g} / \mathrm{L}$ in term and $0.9-6.3 \mu \mathrm{g} / \mathrm{L}$ in preterm mature milk [84].

The TGF- $\beta$ found in BM is of great importance for the newborn as it suppresses the neonatal T-lymphocytes activity [155], enabling oral and intestinal tolerance. It could also reduce atopic sensitization by controlling the inflammatory processes involved [156]. TGF- $\beta$ regulates the production of secretory immunoglobulin A (IgA). IgA in human milk confers passive immune protection to the infant [157]. IgA levels are higher in preterm colostrum $(1.8-16.4 \mathrm{~g} / \mathrm{L})$ than in term colostrum $(1.2-11.6 \mathrm{~g} / \mathrm{L})$. Levels greatly decrease along the lactation period to an average of $0.2-0.8 \mathrm{~g} / \mathrm{L}$ [84]. 
Therefore, TGF- $\beta$-mediated tolerance and IgA antibody synthesis play an essential role in the immunological development of newborns. Some studies have shown how maternal exposure to highly microbial environments increased their TGF- $\beta$ breastmilk concentrations [147], and it has been proposed that the maternal immune mediators are transferred to the infant by the BM. Thus, the increased TGF- $\beta$ and IgA levels in the very first milk reflect their purpose of targeting microbial antigens and improve the mucosal barrier function [158]. It has been proposed that, during the gestational and lactation period, there is an increased synthesis of TGF- $\beta$, due to the infiltration of immune cells into the breast tissue [159]. These studies propose that the local mammary gland production of TGF- $\beta$ may be responsible for the elevated concentrations observed in human milk.

\subsubsection{Inflammatory Cytokines in Human Breastmilk}

Most of the inflammatory cytokines, such as tumor necrosis factor alpha (TNF- $\alpha$ ), IL-1 $\beta$, IL-6, IL-8, and interferon gamma (IFN $\gamma$ ), are present at lower concentrations compared to anti-inflammatory cytokines (Figure 3). The levels of these cytokines decrease over lactation [20] and are associated with the timing of delivery [160], being higher in preterm milk than in term BM [82].

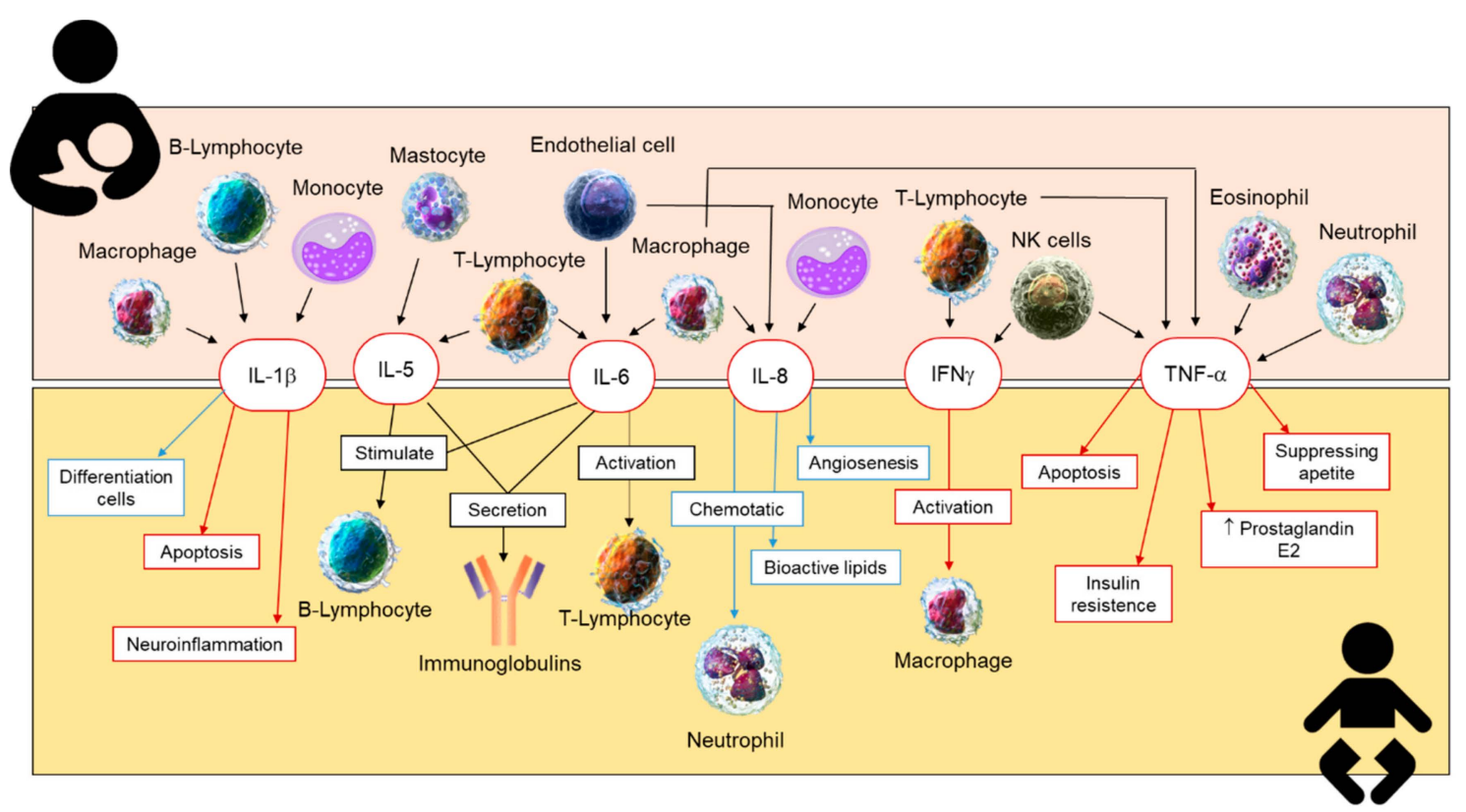

Figure 3. Synthesis of the inflammatory cytokines present in human breastmilk and their effect on the neonate. IL-1 $\beta$, interleukin-1 $\beta$; IL-5, interleukin-5; IL-6, interleukin-6; IL-8, interleukin-8; IFN $\gamma$, interferon gamma; TNF- $\alpha$, tumor necrosis factor alpha.

IL-6 levels range between 4.4 and $340 \mathrm{ng} / \mathrm{L}$ in term colostrum, between 15.3 and $362 \mathrm{ng} / \mathrm{L}$ in preterm colostrum, and between 9.3 and $67.9 \mathrm{ng} / \mathrm{L}$ in very preterm colostrum.

IL-8 concentrations vary between 0.04 and $26.3 \mu \mathrm{g} / \mathrm{L}$ in term colostrum, between 0.13 and $14.7 \mu \mathrm{g} / \mathrm{L}$ in preterm colostrum, and between 0.1 and $3.0 \mu \mathrm{g} / \mathrm{L}$ in very preterm colostrum.

TNF- $\alpha$ levels decrease from an average of $11.4 \mathrm{ng} / \mathrm{L}$ in term colostrum to $1.6 \mathrm{ng} / \mathrm{L}$ in term mature milk, from $18.2 \mathrm{ng} / \mathrm{L}$ in preterm colostrum to $3.2 \mathrm{ng} / \mathrm{L}$ in preterm mature milk, and from $4.2 \mathrm{ng} / \mathrm{L}$ in very preterm colostrum to $1.8 \mathrm{ng} / \mathrm{L}$ in very preterm mature milk [84].

There is a controversy about the effect of these cytokines on the health of offspring [149]. Some reports demonstrate that preterm gestation does not substantially influence the cytokine content of BM during the first month of lactation compared to full-term gestation, which can be beneficial for the regional and systemic immune response of the very preterm infant [152].

IL-1 $\beta$ is a mediator of the inflammatory response, and is involved in cell proliferation, differentiation, and apoptosis. Several studies have obtained a range of between 2 and $2500 \mathrm{pg} / \mathrm{mL}$ for 
IL-1 $\beta$ in human milk [161]. It has been reported that the higher the levels of IL-1 $\beta$ in human milk, the greater the protection against eczema for infants [96].

IFN $\gamma$ improves the Th1/inflammation response while abolishing the Th2/allergic reaction [145]. The colostrum of allergic mothers contains less IFN $\gamma$ but more Th2, IL-4 and IL-13 when compared to non-allergic mothers [162].

Other studies have demonstrated that IL- 8 and TNF $\alpha$ levels are slightly elevated in advanced BM of mothers who suffered from preeclampsia [163]. However, not all studies reveal a negative effect of the inflammatory cytokines. IL-8 also protects intestinal cells against chemical injury, since it has a trophic function in the developing human intestine [151]. Other authors have shown the relevance of cytokines as risk factors for immunological disease in infants. Thus, the presence of IL-5 and IL-13 in human milk, although extremely low, are risk factors for asthma at the age of one [164].

More research is needed on the role of cytokines in BM and how they influence neonatal health. The contribution of cytokines, anti and pro-inflammatory in BM, is different, and this variability could make the difference between health and disease in preterm infants.

\section{Human Milk Cells}

\subsection{Stem Cells in Human Milk}

Recent data suggest that up to $6 \%$ of the cells in human milk are stem cells, and mesenchymal stem cells isolated from BM are potentially reprogrammable to multiple tissue types $[165,166]$. These cells may be involved in the development of immune cells including the regulatory $\mathrm{T}$ cell, which may produce tolerance to non-inherited maternal antigens and suppress anti-maternal immunity. It induces pregnancy microchimerism, leading to intestinal tissue repair and immune development and protection against infectious diseases [166].

\subsection{Leukocytes in Human Milk}

Leukocytes are highly present in colostrum, which means that breastfed infants are exposed to up to 1010 maternal leukocytes/day [167]; however the contribution of this exposure in infants' immune development is not yet clear [148]. A study carried out with 61 mothers and neonates showed a significantly smaller proportion of macrophages in BM of mothers with infants that developed an allergy to cow's milk. In contrast, a higher content of neutrophils, eosinophils, or lymphocytes was associated with lower allergies to cow's milk [168].

The role of these cells is still far from understood; for example, how these cells pass the stomach and intestinal barriers and access the infant, or their mechanisms of action, remain unclear. Therefore, further research to clarify these aspects of the inflammation and immunity development is required.

\section{Human Milk Microbiota}

Early microbial colonization is essential for the infant's metabolic and immunological maturation. Its development begins at birth, and the most important changes occur during the first year of life $[169,170]$. The microbiome is constantly changing, and it is influenced by hormones, cytokines, and chemokines. After birth, the transference continues along breastfeeding, and it is considered the main cause of variability between exclusively breastfed and formula-fed infants during the first months of life $[165,171]$. Raw BM is not a sterile food [167] and several reports confirm more than 100 types of viable bacteria/mL in human milk [171], including $65 \%$ of the phyla Proteobacteria and $34 \%$ of the phyla Firmicutes [82]. Regarding the genera, the most common are Staphylococcus, Streptococcus, Lactobacillus, Enterococcus, Lactococcus, Weissella, Veillonella, and Bifidobacterium [172,173]. It has been described that human milk microbiota at an early age is strongly linked with other perinatal factors such as place of residence, delivery mode, or maternal food intake [96]. With respect to the comparison between preterm and term milk, few studies have reported a difference in the BM microbiome. Some trends include more Bifidobacterium in term milk and more Enterococcus in preterm milk $[97,167]$. 
The association between the microbiome and various disorders, such as visceral pain, autism spectrum disorder, cardiovascular risk, obesity, depression, or multiple sclerosis, has been well demonstrated. Besides, the microbiota exerts immune-modulating effects that influence allergic reactions [169]. Thus, the gut microbiome from allergic children differs from non-allergic ones in composition and diversity [174]. It has been hypothesized that early gut colonizers could help in developing and maturing the immune system in infants [175]. Probiotic intake throughout gestation and lactation also leads to specific changes in the neonate [176]. A clinical trial reports the beneficial effect of oral supplementation with Lactobacillus rhamnosus in women during pregnancy and breastfeeding to reduce the allergy risk in infants. Modulatory effects were observed both on milk composition and the infant gut [177]. Variations in microbiota of preterm infants have been associated with a higher predisposition for developing NEC [178]. Taking together the information available, BM could be considered a probiotic food for infants. However, the potential protective effect of the BM microbiome is not fully understood, and additional research in this area is necessary to understand its role in the newborn's health.

\section{Conclusions and Proposal for Future Research}

Breastmilk is a complex food and is the gold standard for infant nutrition. The aim of the present review was to summarize current knowledge regarding some important bioactive molecules which participate in growth, defense against oxidative damage, and infections, and are particularly important in prematurity, which is a global rising problem.

Breastmilk is a dynamic fluid; it is known that its macronutrient composition changes along lactation to match infant needs. The present review provides evidence that bioactive factors also change over time and, in general, the highest levels are found in colostrum. Another relevant conclusion is that bioactive factors are higher in preterm compared to full-term milk. However, the review of the literature evidences some controversy. Regarding antioxidants, there is no consensus in relation to the content and the requirements in preterm and full-term infants, and there is insufficient information on the changes in donated milk due to thermal treatments. The growth factors and adipokines present in breastmilk, together with macronutrients, contribute to organ maturation and development. The issues that deserve further investigation include how maternal dietary habits or metabolic status influence the content of these bioactive compounds. Accessibility of cytokines from breastmilk is important to modulate the immediate and long-term inflammatory response of the infant. There is no consensus on the concentrations of different cytokines in breastmilk and their relative role for neonatal and adult health, an aspect that deserves further investigation. Finally, the immune-modulating effects of breastmilk leucocytes, stem cells, and the microbiota are still far from being understood, and represent an expanding field of research.

Another conclusion is the insufficient clinical evidence to demonstrate that raw breastmilk is better than donated milk for infant growth. However, due to the better content of bioactive factors, it is possible that it may improve other clinical outcomes such neurodevelopment or prevention of adult diseases.

Among aspects which require further attention, we suggest several research lines. Firstly, it is necessary to improve and systematize methods to quantify bioactive factors in breastmilk. It would also be of interest to gain insight on how body fat, nutritional status, and health of the mother influence bioactive breastmilk factors. The results obtained from these studies may help to improve clinical practice, particularly in preterm infants, in the progress of treatments to preserve bioactive factors in donated milk, and to design formula milk that best matches infant needs. Increasing knowledge in this area may help to regulate and adjust neonatal infant growth and improve neonatal and long-term health.

Author Contributions: Conceptualization: A.G.-D., S.M.A., M.A.M.-C., Á.L.L.d.P. and D.R.-C.; Methodology and Resources: A.G.-D., S.M.A., Á.L.L.d.P., D.R.-C.; Writing—Original Draft Preparation, A.G.-D., A.A. and D.R.-C.; 
Supervision, S.M.A.; Writing—Review and Editing: A.G.-D., S.M.A., M.A.M.-C., Á.L.L.d.P., M.S.P. and D.R.-C.; Funding Acquisition: S.M.A. and M.A.M.-C.

Funding: This work was supported by Ministerio de Economia y Competitividad (grant number FEM2015-63631-R) to SMA and the Ministerio de Ciencia, Innovación y Universidades (Spain) (grant number RTI2018-097504-B-100) to SMA and MAM-C. Both grants were co-financed with FEDER funds.

Acknowledgments: We would like to thank Raquel Fuertes Ortega, a professional translator, for English editing.

Conflicts of Interest: The authors declare no conflict of interest.

\section{References}

1. Guaraldi, F.; Salvatori, G. Effect of Breast and Formula Feeding on Gut Microbiota Shaping in Newborns. Front. Cell. Infect. Microbiol. 2012, 2, 94. [CrossRef]

2. World Health Organization: Preterm Birth. Available online: https://bit.ly/2RWokG3 (accessed on 23 November 2018).

3. Blencowe, H.; Cousens, S.; Chou, D.; Oestergaard, M.; Say, L.; Moller, A.; Kinney, M. Born Too Soon: The Global Epidemiology of 15 Million Preterm Births. Reprod. Health 2013, 10, 1-14. [CrossRef] [PubMed]

4. Harrison, M.S.; Goldenberg, R.L. Global Burden of Prematurity. Semin. Fetal Neonatal Med. 2016, 21, 74-79. [CrossRef] [PubMed]

5. Iams, J.D.; Romero, R.; Culhane, J.F.; Goldenberg, R.L. Primary, Secondary, and Tertiary Interventions to Reduce the Morbidity and Mortality of Preterm Birth. Lancet 2008, 371, 164-175. [CrossRef]

6. Ion, R.; López Bernal, A. Smoking and Preterm Birth. Reprod. Sci. 2015, 22, 918-926. [CrossRef] [PubMed]

7. Al-gubory, K. Environmental Pollutants and Lifestyle Factors Induce Oxidative Stress and Poor Prenatal Development. Reprod. Biomed. Online 2014, 29, 17-31. [CrossRef] [PubMed]

8. Simón, L.; Pastor-Barriuso, R.; Boldo, E.; Fernández-Cuenca, R.; Ortiz, C.; Linares, C.; Medrano, M.J.; Galán, I. Smoke-Free Legislation in Spain and Prematurity. Pediatrics 2017, 139, e20162068. [CrossRef]

9. Blencowe, H.; Cousens, S.; Oestergaard, M.Z.; Chou, D.; Moller, A.-B.; Narwal, R.; Adler, A.; Garcia, C.V.; Rohde, S.; Say, L.; et al. National, Regional, and Worldwide Estimates of Preterm Birth Rates in the Year 2010 with Time Trends since 1990 for Selected Countries: A Systematic Analysis and Implications. Lancet 2012, 379, 2162-2172. [CrossRef]

10. Schanler, R.J.; Shulman, R.J.; Lau, C. Feeding Strategies for Premature Infants: Beneficial Outcomes of Feeding Fortified Human Milk Versus Preterm Formula. Pediatrics 1999, 103, 1150-1157. [CrossRef]

11. Meinzen-Derr, J.; Poindexter, B.; Wrage, L.; Morrow, A.L.; Stoll, B.; Donovan, E.F. Role of Human Milk in Extremely Low Birth Weight Infants' Risk of Necrotizing Enterocolitis or Death. J. Perinatol. 2009, 29, 57-62. [CrossRef]

12. Maayan-Metzger, A.; Avivi, S.; Schushan-Eisen, I.; Kuint, J. Human Milk Versus Formula Feeding Among Preterm Infants: Short-Term Outcomes. Am. J. Perinatol. 2012, 29, 121-126. [CrossRef] [PubMed]

13. Reiterer, F.; Scheuchenegger, A.; Resch, B.; Maurer-Fellbaum, A.; Avian, A.; Urlesberger, B. Outcomes of Very Preterm Infants with and without BPD Followed to Preschool Age. Pediatr. Int. 2019, 61, 381-387. [CrossRef] [PubMed]

14. Isaacs, E.B.; Fischl, B.R.; Quinn, B.T.; Chong, W.K.; Gadian, D.G.; Lucas, A. Impact of Breast Milk on Intelligence Quotient, Brain Size, and White Matter Development. Pediatr. Res. 2010, 67, 357-362. [CrossRef] [PubMed]

15. Parkinson, J.R.C.; Hyde, M.J.; Gale, C.; Santhakumaran, S.; Modi, N. Preterm Birth and the Metabolic Syndrome in Adult Life: A Systematic Review and Meta-Analysis. Pediatrics 2013, 131, e1240-e1263. [CrossRef]

16. Lapillonne, A.; Griffin, I.J. Feeding Preterm Infants Today for Later Metabolic and Cardiovascular Outcomes. J. Pediatr. 2013, 162, S7-S16. [CrossRef] [PubMed]

17. Howson, C.P.; Kinney, M.V.; Mcdougall, L.; Lawn, J.E. Born Too Soon: Preterm Birth Matters. Reprod. Health 2013, 10, 1-9. [CrossRef] [PubMed]

18. Castillo-Castañeda, P.C.; Gaxiola-Robles, R.; Méndez-Rodríguez, L.C.; Zenteno-Savín, T. Defensas Antioxidantes En Leche Materna En Relación Al Número De Gestas Y A La Edad De Las Madres. Nutr. Hosp. 2014, 30, 540-547. [PubMed] 
19. Castillo-Castañeda, P.C.; García-González, A.; Bencomo-Alvarez, A.E.; Barros-Nuñez, P.; Gaxiola-Robles, R.; Celina Méndez-Rodríguez, L.; Zenteno-Savín, T. Micronutrient Content and Antioxidant Enzyme Activities in Human Breast Milk. J. Trace Elem. Med. Biol. 2019, 51, 36-41. [CrossRef] [PubMed]

20. Ballard, O.; Morrow, A.L. Human Milk Composition: Nutrients and Bioactive Factors. Pediatr. Clin. N. Am. 2013, 60, 49-74. [CrossRef] [PubMed]

21. World Health Organization: Exclusive Breastfeeding. Available online: https://bit.ly/2FaaEkE (accessed on 23 November 2018).

22. World Health Organization: Infant and Young Child Feeding. Available online: https://bit.ly/2VyOnRL (accessed on 5 March 2019).

23. American Academy of Pediatrics. Breastfeeding and the Use of Human Milk. Pediatrics 2012, 129, e827-e841. [CrossRef] [PubMed]

24. Singhal, A.; Sadaf Farooqi, I.; O’Rahilly, S.; Cole, T.J.; Fewtrell, M.; Lucas, A. Early Nutrition and Leptin Concentrations in Later Life. Am. J. Clin. Nutr. 2002, 75, 993-999. [CrossRef] [PubMed]

25. Lessen, R.; Kavanagh, K. Practice Paper of the Academy of Nutrition and Dietetics Abstract: Promoting and Supporting Breastfeeding. J. Acad. Nutr. Diet. 2015, 115, 450. [CrossRef]

26. Yuksel, S.; Yigit, A.A.; Cinar, M.; Atmaca, N.; Onaran, Y. Oxidant and Antioxidant Status of Human Breast Milk During Lactation Period. Dairy Sci. Technol. 2015, 95, 295-302. [CrossRef]

27. Singhal, A.; Cole, T.J.; Lucas, A. Early Nutrition in Preterm Infants and Later Blood Pressure: Two Cohorts after Randomised Trials. Lancet 2001, 357, 413-419. [CrossRef]

28. Cubero, J.; Sánchez, C.L.; Bravo, R.; Sánchez, J.; Rodriguez, A.B.; Rivero, M.; Barriga, C. Analysis of the Antioxidant Activity in Human Milk, Day Vs. Night. Cell Membr. Free Radic. Res. 2009, 1, 100-101.

29. De Vicente, B. 1 De Cada 5 Bebés no Recibe Leche Materna En Los Países Ricos. Available online: https://bit.ly/2RiYzeR (accessed on 21 January 2019).

30. Heiman, H.; Schanler, R.J. Nutrición Enteral En Prematuros: El Rol De La Leche Humana. Rev. Enferm. 2007, 12, 26-34.

31. Hanson, C.; Lyden, E.; Furtado, J.; Van Ormer, M.; Anderson-Berry, A. A Comparison of Nutritional Antioxidant Content in Breast Milk, Donor Milk, and Infant Formulas. Nutrients 2016, 8, 681. [CrossRef]

32. Mehta, R.; Petrova, A. Is Variation in Total Antioxidant Capacity of Human Milk Associated with Levels of Bio-Active Proteins? J. Perinatol. 2014, 34, 220-222. [CrossRef]

33. Savino, F.; Benetti, S.; Liguori, S.A.; Sorrenti, M.; Montezemolo, L.C. Di Advances on Human Milk Hormones and Protection Against Obesity. Cell. Mol. Biol. 2013, 59, 89-98.

34. Garwolińska, D.; Namieśnik, J.; Kot-Wasik, A.; Hewelt-Belka, W. Chemistry of Human Breast Milk-A Comprehensive Review of the Composition and Role of Milk Metabolites in Child Development. J. Agric. Food Chem. 2018, 66, 11881-11896. [CrossRef]

35. Mutinati, M.; Pantaleo, M.; Roncetti, M.; Piccinno, M.; Rizzo, A.; Sciorsci, R.L. Oxidative Stress in Neonatology: A Review. Reprod. Domest. Anim. 2014, 49, 7-16. [CrossRef] [PubMed]

36. Wilinska, M.; Borszewska-Kornacka, M.K.; Niemiec, T.; Jakiel, G. Oxidative Stress and Total Antioxidant Status in Term Newborns and Their Mothers. Ann. Agric. Environ. Med. 2015, 22, 736-740. [CrossRef] [PubMed]

37. Aceti, A.; Beghetti, I.; Martini, S.; Faldella, G.; Corvaglia, L. Oxidative Stress and Necrotizing Enterocolitis: Pathogenetic Mechanisms, Opportunities for Intervention, and Role of Human Milk. Oxid. Med. Cell. Longev. 2018, 2018, 1-7. [CrossRef] [PubMed]

38. Thibeault, D.W. The Precarious Antioxidant Defenses of the Preterm Infant. Am. J. Perinatol. 2000, 17, 167-182. [CrossRef] [PubMed]

39. Ahmad, P.; Jaleel, C.A.; Salem, M.A.; Nabi, G.; Sharma, S. Roles of Enzymatic and Nonenzymatic Antioxidants in Plants During Abiotic Stress. Crit. Rev. Biotechnol. 2010, 30, 161-175. [CrossRef] [PubMed]

40. Friel, J.K.; Martin, S.M.; Langdon, M.; Herzberg, G.R.; Buettner, G.R. Milk from Mothers of Both Premature and Full-Term Infants Provides Better Antioxidant Protection than Does Infant Formula. Pediatr. Res. 2002, 51, 612-618. [CrossRef]

41. Gutiérrez-Repiso, C.; Velasco, I.; Garcia-Escobar, E.; Garcia-Serrano, S.; Rodríguez-Pacheco, F.; Linares, F.; Ruiz De Adana, M.S.; Rubio-Martin, E.; Garrido-Sanchez, L.; Cobos-Bravo, J.F.; et al. Does Dietary Iodine Regulate Oxidative Stress and Adiponectin Levels in Human Breast Milk? Antioxid. Redox Signal. 2014, 20, 847-853. [CrossRef] 
42. Ledo, A.; Arduini, A.; Asensi, M.A.; Sastre, J.; Escrig, R.; Brugada, M.; Aguar, M.; Saenz, P.; Vento, M. Human Milk Enhances Antioxidant Defenses Against Hydroxyl Radical Aggression in Preterm Infants. Am. J. Clin. Nutr. 2009, 89, 210-215. [CrossRef]

43. Friel, J.K.; Diehl-Jones, B.; Cockell, K.A.; Chiu, A.; Rabanni, R.; Davies, S.S.; Jackson Roberts, L. Evidence of Oxidative Stress in Relation to Feeding Type During Early Life in Premature Infants. Pediatr. Res. 2011, 69, 160-164. [CrossRef]

44. Quiles, J.L.; Ochoa, J.J.; Ramirez-Tortosa, M.C.; Linde, J.; Bompadre, S.; Battino, M.; Narbona, E.; Maldonado, J.; Mataix, J. Coenzyme Q Concentration and Total Antioxidant Capacity of Human Milk at Different Stages of Lactation in Mothers of Preterm and Full-Term Infants. Free Radic. Res. 2006, 40, 199-206. [CrossRef]

45. Zarban, A.; Taheri, F.; Chahkandi, T.; Sharifzadeh, G.; Khorashadizadeh, M. Antioxidant and Radical Scavenging Activity of Human Colostrum, Transitional and Mature Milk. J. Clin. Biochem. Nutr. 2009, 45, 150-154. [CrossRef] [PubMed]

46. Ankrah, N.A.; Appiah-Opong, R.; Dzokoto, C. Human Breastmilk Storage and the Glutathione Content. J. Trop. Pediatr. 2000, 46, 111-113. [CrossRef] [PubMed]

47. Hernández-Aguilar, M.T.; De La Torre, M.J.L.; Borja-Herrero, C.; Lasarte-Velillas, J.J.; Martorell-Juan, L. Antioxidant Properties of Human Milk. J. Pediatr. Biochem. 2013, 3, 161-167.

48. Hamprecht, K.; Goelz, R. Postnatal Cytomegalovirus Infection through Human Milk in Preterm Infants. Clin. Perinatol 2016, 44, 121-130. [CrossRef] [PubMed]

49. Allen, A.A.; Baquero-Artiago, F. Review and Guidelines on the Prevention, Diagnosis and Treatment of Post-Natal Cytomegalovirus Infection. J. Pediatr (Barc) 2011, 74, 52.e1-52.e13.

50. Păduraru, L.; Dimitriu, D.C.; Avasiloaiei, A.L.; Moscalu, M.; Zonda, G.I.; Stamatin, M. Total Antioxidant Status in Fresh and Stored Human Milk from Mothers of Term and Preterm Neonates. Pediatr. Neonatol. 2018, 59, 600-605. [CrossRef] [PubMed]

51. Xavier, A.M.; Rai, K.; Hegde, A.M. Total Antioxidant Concentrations of Breastmilk-An Eye-Opener to the Negligent. J. Heal. Popul. Nutr. 2011, 29, 605-611. [CrossRef]

52. Young, I.; Woodside, J. Antioxidants in Health and Disease. J. Clin. Pathol. 2001, 54, 176-186. [CrossRef]

53. Goyal, M.M.; Basak, A. Human Catalase: Looking for Complete Identity. Protein Cell 2010, 1, 888-897. [CrossRef]

54. Brigelius-Flohé, R. Tissue-Specific Functions of Individual Glutathione Peroxidases. Free Radic. Biol. Med. 1999, 27, 951-965. [CrossRef]

55. Groussard, C.; Rannou-Bekono, F.; Machefer, G.; Chevanne, M.; Vincent, S.; Sergent, O.; Cillard, J.; Gratas-Delamarche, A. Changes in Blood Lipid Peroxidation Markers and Antioxidants after a Single Sprint Anaerobic Exercise. Eur. J. Appl. Physiol. 2003, 89, 14-20. [CrossRef] [PubMed]

56. Silvestre, D.; Miranda, M.; Muriach, M.; Almansa, I.; Jareno, E.; Romero, F.J. Antioxidant Capacity of Human Milk: Effect of Thermal Conditions for the Pasteurization. Acta Paediatr. 2008, 97, 1070-1074. [CrossRef] [PubMed]

57. Ballatori, N.; Krance, S.M.; Notenboom, S.; Shi, S.; Tieu, K.; Hammond, C.L. Glutathione Dysregulation and the Etiology and Progression of Human Diseases. Biol. Chem. 2009, 390, 191-214. [CrossRef] [PubMed]

58. Valko, M.; Leibfritz, D.; Moncol, J.; Cronin, M.T.D.; Mazur, M.; Telser, J. Free Radicals and Antioxidants in Normal Physiological Functions and Human Disease. Int. J. Biochem. Cell Biol. 2007, 39, 44-84. [CrossRef] [PubMed]

59. Liebmann, P.M.; Wölfler, A.; Felsner, P.; Holfer, D.; Schauenstein, K. Melatonin and the Immune System. Int. Arch. Allergy Immunol. 1997, 112, 203-211. [CrossRef] [PubMed]

60. Reiter, R.J. Antioxidant Actions of Melatonin. Adv. Pharmacol. 1996, 38, 103-117.

61. Kennaway, D.J.; Wright, H. Melatonin and Circadian Rhythms. Curr. Top. Med. Chem. 2002, 2, 199-209. [CrossRef] [PubMed]

62. Blask, D.E.; Sauer, L.A.; Dauchy, R.T. Melatonin as a Chronobiotic/Anticancer Agent: Cellular, Biochemical, and Molecular Mechanisms of Action and Their Implications for Circadian-Based Cancer Therapy. Curr. Top. Med. Chem. 2002, 2, 113-132. [CrossRef]

63. Cuzzocrea, S.; Reiter, R.J. Pharmacological Actions of Melatonin in Acute and Chronic Inflammation. Curr. Top. Med. Chem. 2002, 2, 153-165. [CrossRef]

64. Guerrero, J.M.; Reiter, R.J. Melatonin-Immune System Relationships. Curr. Top. Med. Chem. 2002, 2, 167-179. [CrossRef] 
65. Reiter, R.J.; Tan, D.X.; Cabrera, J.; D'Arpa, D.; Sainz, R.M.; Mayo, J.C.; Ramos, S. The Oxidant/Antioxidant Network: Role of Melatonin. Biol. Signals Recept. 1999, 8, 56-63. [CrossRef] [PubMed]

66. Reiter, R.J.; Tan, D.-X. What Constitutes a Physiological Concentration of Melatonin? J. Pineal Res. 2003, 34, 79-80. [CrossRef] [PubMed]

67. Tan, D.; Hardeland, R.; Manchester, L.C.; Poeggeler, B.; Lopez-Burillo, S.; Mayo, J.C.; Sainz, R.M.; Reiter, R.J. Mechanistic and Comparative Studies of Melatonin and Classic Antioxidants in Terms of Their Interactions with the ABTS Cation Radical. J. Pineal Res. 2003, 34, 249-259. [CrossRef] [PubMed]

68. Bonnefont-Rousselot, D.; Collin, F. Melatonin: Action as Antioxidant and Potential Applications in Human Disease and Aging. Toxicology 2010, 278, 55-67. [CrossRef] [PubMed]

69. Colella, M.; Biran, V.; Baud, O. Melatonin and the Newborn Brain. Early Hum. Dev. 2016, 102, 1-3. [CrossRef] [PubMed]

70. Melatonin. Drugs and Lactation Database (LactMed); National Library of Medicine (US): Bethesda, MD, USA, 2006.

71. Shelby, R.D.; Cromeens, B.; Rager, T.M.; Besner, G.E. Influence of Growth Factors on the Development of Necrotizing Enterocolitis. Clin. Perinatol. 2019, 46, 51-64. [CrossRef]

72. Lawrence, R.M.; Pane, C.A. Human Breast Milk: Current Concepts of Immunology and Infectious Diseases. Curr. Probl. Pediatr. Adolesc. Health Care 2007, 37, 7-36. [CrossRef]

73. Loui, A.; Eilers, E.; Strauss, E.; Pohl-Schickinger, A.; Obladen, M.; Koehne, P. Vascular Endothelial Growth Factor (VEGF) and Soluble VEGF Receptor 1 (sFlt-1) Levels in Early and Mature Human Milk from Mothers of Preterm versus Term Infants. J. Hum. Lact. 2012, 28, 522-528. [CrossRef]

74. Hirai, C.; Ichiba, H.; Saito, M.; Shintaku, H.; Yamano, T.; Kusuda, S. Trophic Effect of Multiple Growth Factors in Amniotic Fluid or Human Milk on Cultured Human Fetal Small Intestinal Cells. J. Pediatr. Gastroenterol. Nutr. 2002, 34, 524-528. [CrossRef]

75. Munblit, D.; Abrol, P.; Sheth, S.; Chow, L.Y.; Khaleva, E.; Asmanov, A.; Lauriola, S.; Padovani, E.M.; Comberiati, P.; Boner, A.L.; et al. Levels of Growth Factors and Iga in the Colostrum of Women from Burundi and Italy. Nutrients 2018, 10, 1216. [CrossRef]

76. Funakoshi, H.; Nakamura, T. Hepatocyte Growth Factor: From Diagnosis to Clinical Applications. Clin. Chim. Acta 2003, 327, 1-23. [CrossRef]

77. Kobata, R.; Tsukahara, H.; Ohshima, Y.; Ohta, N.; Tokuriki, S.; Tamura, S.; Mayumi, M. High Levels of Growth Factors in Human Breast Milk. Early Hum. Dev. 2008, 84, 67-69. [CrossRef] [PubMed]

78. Min, J.-K.; Lee, Y.-M.; Kim, J.H.; Kim, Y.-M.; Kim, S.W.; Lee, S.-Y.; Gho, Y.S.; Oh, G.T.; Kwon, Y.-G. Hepatocyte Growth Factor Suppresses Vascular Endothelial Growth Factor-Induced Expression of Endothelial ICAM-1 and VCAM-1 by Inhibiting the Nuclear Factor-кB Pathway. Circ. Res. 2005, 96, 300-307. [CrossRef] [PubMed]

79. Wagner, C.L.; Taylor, S.N.; Johnson, D. Host factors in amniotic fluid and breast milk that contribute to gut maturation. Clin. Rev. Allergy Immunol. 2008, 34, 191-204. [CrossRef] [PubMed]

80. Chang, C.-J.; Chao, J.C.-J. Effect of human milk and epidermal growth factor on growth of human intestinal Caco-2 cells. J. Pediatr. Gastroenterol. Nutr. 2002, 34, 394-401. [CrossRef]

81. Radulescu, A.; Zhang, H.-Y.; Chen, C.-L.; Chen, Y.; Zhou, Y.; Yu, X.; Otabor, I.; Olson, J.K.; Besner, G.E. Heparin-Binding EGF-Like Growth Factor promotes intestinal anastomotic healing. J. Surg. Res. 2012, 171, 540-550. [CrossRef] [PubMed]

82. Gregory, K.E.; Walker, W.A. Immunologic factors in human milk and disease prevention in the preterm infant. Curr. Pediatr. Rep. Online 2013, 1, 222-228. [CrossRef]

83. Dvorak, B.; Fituch, C.C.; Williams, C.S.; Hurst, N.M.; Schanler, R.J. Increased Epidermal Growth Factor Levels in Human Milk of Mothers with Extremely Premature Infants. Pediatr. Res. 2003, 54, 15-19. [CrossRef]

84. Castellote, C.; Casillas, R.; Ramírez-Santana, C.; Pérez-Cano, F.J.; Castell, M.; Moretones, M.G.; López-Sabater, M.C.; Franch, A. Premature Delivery Influences the Immunological Composition of Colostrum and Transitional and Mature Human Milk. J. Nutr. 2011, 110, 1181-1187. [CrossRef]

85. Boesmans, W.; Gomes, P.; Janssens, J.; Tack, J.; Vanden Berghe, P. Brain-derived neurotrophic factor amplifies neurotransmitter responses and promotes synaptic communication in the enteric nervous system. Gut 2008, 57, 314-322. [CrossRef]

86. Ismail, A.M.; Babers, G.M.; El Rehany, M.A. Brain-Derived Neurotrophic Factor in Sera of Breastfed Epileptic Infants and in Breastmilk of Their Mothers. Breastfeed. Med. 2015, 10, 277-282. [CrossRef] [PubMed] 
87. Li, R.; Xia, W.; Zhang, Z.; Wu, K. S100b protein, brain-derived neurotrophic factor, and glial cell line-derived neurotrophic factor in human milk. PLoS ONE 2011, 6, e21663. [CrossRef] [PubMed]

88. Blum, J.W.; Baumrucker, C.R. Colostral and milk insulin-like growth factors and related substances: Mammary gland and neonatal (intestinal and systemic) targets. Domest. Anim. Endocrinol. 2002, 23, 101-110. [CrossRef]

89. Milsom, S.R.; Blum, W.F.; Gunn, A.J. Temporal changes in insulin-like growth factors I and II and in insulin-like growth factor binding proteins 1, 2, and 3 in human milk. Horm. Res. 2008, 69, 307-311. [CrossRef] [PubMed]

90. Ozgurtas, T.; Aydin, I.; Turan, O.; Koc, E.; Hirfanoglu, I.M.; Acikel, C.H.; Akyol, M.; Erbil, M.K. Vascular endothelial growth factor, basic fibroblast growth factor, insulin-like growth factor-I and platelet-derived growth factor levels in human milk of mothers with term and preterm neonates. Cytokine 2010, 50, 192-194. [CrossRef] [PubMed]

91. Elmlinger, M.W.; Hochhaus, F.; Loui, A.; Frommer, K.W.; Obladen, M.; Ranke, M.B. Insulin-like growth factors and binding proteins in early milk from mothers of preterm and term infants. Horm. Res. 2007, 68, 124-131. [CrossRef] [PubMed]

92. Lenhartova, N.; Matasova, K.; Lasabova, Z.; Javorka, K.; Calkovska, A. Impact of early aggressive nutrition on retinal development in premature infants. Physiol. Res. 2017, 66, S215-S226. [PubMed]

93. Shimizu, H.; Ohsaki, A.; Oh-I, S.; Okada, S.; Mori, M. A new anorexigenic protein, nesfatin-1. Peptides 2009, 30, 995-998. [CrossRef] [PubMed]

94. Tapping, R.I.; Tobias, P.S. Soluble CD14-Mediated Cellular Responses to Lipopolysaccharide. Chem. Immunol. 2000, 74, 108-121. [PubMed]

95. Ulevitch, R.J.; Tobias, P.S. Receptor-Dependent Mechanisms of Cell Stimulation by Bacterial Endotoxin. Annu. Rev. Immunol. 1995, 13, 437-457. [CrossRef] [PubMed]

96. Munblit, D.; Peroni, D.G.; Boix-Amorós, A.; Hsu, P.S.; Land, B.V.; Gay, M.C.L.; Kolotilina, A.; Skevaki, C.; Boyle, R.J.; Collado, M.C.; et al. Human Milk and Allergic Diseases: An Unsolved Puzzle. Nutrients 2017, 9 , 894. [CrossRef] [PubMed]

97. Khodayar-Pardo, P.; Mira-Pascual, L.; Collado, M.C.; Martínez-Costa, C. Impact of lactation stage, gestational age and mode of delivery on breast milk microbiota. J. Perinatol. 2014, 34, 599-605. [CrossRef] [PubMed]

98. Kalliomäki, M.; Ouwehand, A.; Arvilommi, H.; Kero, P.; Isolauri, E. Transforming growth factor- $\beta$ in breast milk: A potential regulator of atopic disease at an early age. J. Allergy Clin. Immunol. 1999, 104, 1251-1257. [CrossRef]

99. Serrao, F.; Papacci, P.; Costa, S.; Giannantonio, C.; Cota, F.; Vento, G.; Romagnoli, C. Effect of early expressed human milk on insulin-like growth factor 1 and short-term outcomes in preterm infants. PLoS ONE 2016, 11, e0168139. [CrossRef] [PubMed]

100. Saso, A.; Blyuss, O.; Munblit, D.; Faal, A.; Moore, S.E.; Doare, K. Le Breast Milk Cytokines and Early Growth in Gambian Infants. Front. Pediatr. 2019, 6, 414. [CrossRef] [PubMed]

101. Savino, F.; Liguori, S.A.; Lupica, M.M. Adipokines in breast milk and preterm infants. Early Hum. Dev. 2010, 86, 77-80. [CrossRef] [PubMed]

102. Catli, G.; Anik, A.; Tuhan, H.Ü.; Kume, T.; Bober, E.; Abaci, A. The relation of leptin and soluble leptin receptor levels with metabolic and clinical parameters in obese and healthy children. Peptides 2014, 56, 72-76. [CrossRef] [PubMed]

103. Sagawa, N.; Yura, S.; Itoh, H.; Kakui, K.; Takemura, M.; Nuamah, M.A.; Ogawa, Y.; Masuzaki, H.; Nakao, K.; Fujii, S. Possible role of placental leptin in pregnancy: A review. Endocrine 2002, 19, 65-71. [CrossRef]

104. Savino, F.; Liguori, S.; Fissore, M.; Oggero, R. Breast Milk Hormones and Their Protective Effect on Obesity. Int. J. Pediatr. Endocrinol. 2009, 2009, 1-8. [CrossRef]

105. Smith-Kirwin, S.; O'Connor, D.; De Johnston, J.; Lancey, E.; Hassink, S.; Funanage, V. Leptin expression in human mammary epithelial cells and breast milk. J. Clin. Endocrinol. Metab. 1998, 83, 1810-1813. [CrossRef]

106. Casabiell, X.; Piñeiro, V.; Tomé, M.A.; Peinó, R.; Diéguez, C.; Casanueva, F.F. Presence of leptin in colostrum and/or breast milk from lactating mothers: A potential role in the regulation of neonatal food intake. J. Clin. Endocrinol. Metab. 1997, 82, 4270-4273. [CrossRef] [PubMed]

107. Yu, X.; Rong, S.S.; Sun, X.; Ding, G.; Wan, W.; Zou, L.; Wu, S.; Li, M.; Wang, D. Associations of breast milk adiponectin, leptin, insulin and ghrelin with maternal characteristics and early infant growth: A longitudinal study. Br. J. Nutr. 2018, 120, 1380-1387. [CrossRef] [PubMed] 
108. Eilers, E.; Ziska, T.; Harder, T.; Plagemann, A.; Obladen, M.; Loui, A. Leptin determination in colostrum and early human milk from mothers of preterm and term infants. Early Hum. Dev. 2011, 87, 415-419. [CrossRef] [PubMed]

109. Houseknecht, K.L.; McGuire, M.K.; Portocarrero, C.P.; McGuire, M.A.; Beerman, K. Leptin is present in human milk and is related to maternal plasma leptin concentration and adiposity. Biochem. Biophys. Res. Commun. 1997, 240, 742-747. [CrossRef] [PubMed]

110. Miralles, O.; Sánchez, J.; Palou, A.; Picó, C. A physiological role of breast milk leptin in body weight control in developing infants. Obesity 2006, 14, 1371-1377. [CrossRef] [PubMed]

111. Uçar, B.; Kırel, B.; Bör, Ö.; Kılıç, F.S.; Doğruel, N.; Durmuş Aydoğdu, S.; Tekin, N. Breast Milk Leptin Concentrations in Initial and Terminal Milk Samples: Relationships to Maternal and Infant Plasma Leptin Concentrations, Adiposity, Serum Glucose, Insulin, Lipid and Lipoprotein Levels. J. Pediatr. Endocrinol. Metab. 2000, 13, 149-156. [CrossRef] [PubMed]

112. A Fields, D.; Demerath, E.W. Relationship of insulin, glucose, leptin, IL-6 and TNF- $\alpha$ in human Breast-Milk with Infant Growth and Body Composition. Pediatr. Obes. 2012, 7, 304-312. [CrossRef]

113. Resto, M.; O'Connor, D.; Leef, K.; Funanage, V.; Spear, M.; Locke, R. Leptin Levels in Preterm Human Breast Milk and Infant Formula. Pediatrics 2001, 108, 1-4. [CrossRef]

114. Dundar, N.O.; Anal, O.; Dundar, B.; Ozkan, H.; Cahskan, S.; Büyükgebiz, A. Longitudinal Investigation of the Relationship between Breast Milk Leptin Levels and Growth in Breast-fed Infants. J. Pediatr. Endocrinol. Metab. 2005, 18, 181-187. [CrossRef]

115. Larsson, M.W.; Lind, M.V.; Larnkjær, A.; Due, A.P.; Blom, I.C.; Wells, J.; Lai, C.T.; Mølgaard, C.; Geddes, D.T.; Michaelsen, K.F. Excessive weight gain followed by catch-down in exclusively breastfed infants: An exploratory study. Nutrients 2018, 10, 1290. [CrossRef]

116. Kubota, N.; Yano, W.; Kubota, T.; Yamauchi, T.; Itoh, S.; Kumagai, H.; Kozono, H.; Takamoto, I.; Okamoto, S.; Shiuchi, T.; et al. Adiponectin Stimulates AMP-Activated Protein Kinase in the Hypothalamus and Increases Food Intake. Cell Metab. 2007, 6, 55-68. [CrossRef] [PubMed]

117. Maeda, N.; Takahashi, M.; Funahashi, T.; Kihara, S.; Nishizawa, H.; Kishida, K.; Nagaretani, H.; Matsuda, M.; Komuro, R.; Ouchi, N.; et al. PPAR $\gamma$ Ligands Increase Expression and Plasma Concentrations of Adiponectin, an Adipose-Derived Protein. Diabetes 2001, 50, 2094-2099. [CrossRef] [PubMed]

118. Luoto, R.; Laitinen, K.; Nermes, M.; Isolauri, E. Impact of maternal probiotic-supplemented dietary counseling during pregnancy on colostrum adiponectin concentration: A prospective, randomized, placebo-controlled study. Early Hum. Dev. 2012, 88, 339-344. [CrossRef] [PubMed]

119. Martin, L.J.; Woo, J.G.; Geraghty, S.R.; Altaye, M.; Davidson, B.S.; Banach, W.; Dolan, L.M.; Ruiz-Palacios, G.M.; Morrow, A.L. Adiponectin is present in human milk and is associated with maternal factors. Am. J. Clin. Nutr. 2006, 83, 1106-1111. [CrossRef] [PubMed]

120. Wang, Y.; Zhang, Z.; Yao, W.; Morrow, A.; Peng, Y. Variation of maternal milk adiponectin and its correlation with infant growth. Chin. J. Pediatr. 2011, 49, 338-343.

121. Dündar, N.O.; Dündar, B.; Cesur, G.; Yilmaz, N.; Sütu, R.; Özgüner, F. Ghrelin and adiponectin levels in colostrum, cord blood and maternal serum. Pediatr. Int. 2010, 52, 622-625. [CrossRef]

122. Ozarda, Y.; Gunes, Y.; Tuncer, G.O. The concentration of adiponectin in breast milk is related to maternal hormonal and inflammatory status during 6 months of lactation. Clin. Chem. Lab. Med. 2012, 50, 911-917. [CrossRef]

123. Weyermann, M.; Brenner, H.; Rothenbacher, D. Adipokines in Human Milk and Risk of Overweight in Early Childhood. Epidemiology 2007, 18, 722-729. [CrossRef]

124. Newburg, D.S.; Woo, J.G.; Morrow, A.L. Characteristics and Potential Functions of Human Milk Adiponectin. J. Pediatr. 2010, 156, S1-S46. [CrossRef]

125. Savino, F.; Sorrenti, M.; Benetti, S.; Lupica, M.M.; Liguori, S.A.; Oggero, R. Resistin and leptin in breast milk and infants in early life. Early Hum. Dev. 2012, 88, 779-782. [CrossRef]

126. Ilcol, Y.O.; Hizli, Z.B.; Eroz, E. Resistin is present in human breast milk and it correlates with maternal hormonal status and serum level of C-reactive protein. Clin. Chem. Lab. Med. 2008, 46, 118-124. [CrossRef] [PubMed]

127. Briana, D.D.; Boutsikou, M.; Baka, S.; Gourgiotis, D.; Marmarinos, A.; Hassiakos, D.; Malamitsi-Puchner, A. Perinatal Changes of Plasma Resistin Concentrations in Pregnancies with Normal and Restricted Fetal Growth. Neonatology 2008, 93, 153-157. [CrossRef] 
128. Ng, P.C.; Lee, C.H.; Lam, C.W.K.; Chan, I.H.S.; Wong, E.; Fok, T.F. Ghrelin in preterm and term newborns: Relation to anthropometry, leptin and insulin. Pediatr. Res. 2005, 58, 725-730. [CrossRef]

129. Van Der Lely, A.J.; Tschöp, M.; Heiman, M.L.; Ghigo, E. Biological, physiological, pathophysiological, and pharmacological aspects of ghrelin. Endocr. Rev. 2004, 25, 426-457. [CrossRef] [PubMed]

130. Aydin, S.; Ozkan, Y.; Erman, F.; Gurates, B.; Kilic, N.; Colak, R.; Gundogan, T.; Catak, Z.; Bozkurt, M.; Akin, O.; et al. Presence of obestatin in breast milk: Relationship among obestatin, ghrelin, and leptin in lactating women. Nutrition 2008, 24, 689-693. [CrossRef] [PubMed]

131. Aydin, S.; Aydin, S.; Ozkan, Y.; Kumru, S. Ghrelin is present in human colostrum, transitional and mature milk. Peptides 2006, 27, 878-882. [CrossRef] [PubMed]

132. Kierson, J.; Dimatteo, D.; Locke, R.; MacKley, A.; Spear, M. Ghrelin and cholecystokinin in term and preterm human breast milk. Acta Paediatr. Int. J. Paediatr. 2006, 95, 991-995. [CrossRef]

133. Aydin, S.; Geckil, H.; Karatas, F.; Donder, E.; Kumru, S.; Kavak, E.C.; Colak, R.; Ozkan, Y.; Sahin, I. Milk and blood ghrelin level in diabetics. Nutrition 2007, 23, 807-811. [CrossRef]

134. Cesur, G.; Ozguner, F.; Yilmaz, N.; Dundar, B. The relationship between ghrelin and adiponectin levels in breast milk and infant serum and growth of infants during early postnatal life. J. Physiol. Sci. 2012, 62, 185-190. [CrossRef]

135. Savino, F.; Petrucci, E.; Lupica, M.M.; Nanni, G.E.; Oggero, R. Assay of ghrelin concentration in infant formulas and breast milk. World J. Gastroenterol. 2011, 17, 1971-1975. [CrossRef]

136. Seim, I.; Walpole, C.; Amorim, L.; Josh, P.; Herington, A.; Chopin, L. The expanding roles of the ghrelin-gene derived peptide obestatin in health and disease. Mol. Cell. Endocrinol. 2011, 340, 111-117. [CrossRef] [PubMed]

137. Osakia, A.; Shimizu, H.; Ishizuka, N.; Suzuki, Y.; Mori, M.; Inoue, S. Enhanced expression of nesfatin/nucleobindin-2 in white adipose tissue of ventromedial hypothalamus-lesioned rats. Neurosci. Lett. 2012, 521, 46-51. [CrossRef] [PubMed]

138. Aydin, S. The presence of the peptides apelin, ghrelin and nesfatin- 1 in the human breast milk, and the lowering of their levels in patients with gestational diabetes mellitus. Peptides 2010, 31, 2236-2240. [CrossRef] [PubMed]

139. Mesmin, C.; Fenaille, F.; Becher, F.; Tabet, J.C.; Ezan, E. Identification and characterization of apelin peptides in bovine colostrum and milk by liquid chromatography-Mass spectrometry. J. Proteome Res. 2011, 10, 5222-5231. [CrossRef] [PubMed]

140. Castan-Laurell, I.; Dray, C.; Attané, C.; Duparc, T.; Knauf, C.; Valet, P. Apelin, diabetes, and obesity. Endocrine 2011, 40, 1-9. [CrossRef] [PubMed]

141. Akcilar, R.; Turgut, S.; Caner, V.; Akcilar, A.; Ayada, C.; Elmas, L.; Özcan, T.O. The effects of apelin treatment on a rat model of type 2 diabetes. Adv. Med. Sci. 2015, 60, 94-100. [CrossRef] [PubMed]

142. Heinonen, M.V.; Purhonen, A.K.; Miettinen, P.; Pääkkönen, M.; Pirinen, E.; Alhava, E.; Åkerman, K.; Herzig, K.H. Apelin, orexin-A and leptin plasma levels in morbid obesity and effect of gastric banding. Regul. Pept. 2005, 130, 7-13. [CrossRef] [PubMed]

143. Lv, S.-Y.; Yang, Y.J.; Qin, Y.J.; Mo, J.R.; Wang, N.B.; Wang, Y.J.; Chen, Q. Central apelin-13 inhibits food intake via the CRF receptor in mice. Peptides 2012, 33, 132-138. [CrossRef]

144. Dinarello, C.A. Proinflammatory cytokines. Chest 2000, 118, 503-508. [CrossRef]

145. Agarwal, S.; Karmaus, W.; Davis, S.; Gangur, V. Immune markers in breast milk and fetal and maternal body fluids: A systematic review of perinatal concentrations. J. Hum. Lact. 2011, 27, 171-186. [CrossRef]

146. Watanabe, M.A.E.; de Oliveira, G.G.; Oda, J.M.M.; Ono, M.A.; Guembarovski, R.L. Cytokines in Human Breast Milk: Immunological Significance for Newborns. Curr. Nutr. Food Sci. 2012, 8, 2-7. [CrossRef]

147. Peroni, D.G.; Pescollderungg, L.; Piacentini, G.L.; Rigotti, E.; Maselli, M.; Watschinger, K.; Piazza, M.; Pigozzi, R.; Boner, A.L. Immune regulatory cytokines in the milk of lactating women from farming and urban environments. Pediatr. Allergy Immunol. 2010, 21, 977-982. [CrossRef] [PubMed]

148. Rajani, P.S.; Seppo, A.E.; Järvinen, K.M. Immunologically Active Components in Human Milk and Development of Atopic Disease, With Emphasis on Food Allergy, in the Pediatric Population. Front. Pediatr. 2018, 6, 6. [CrossRef] [PubMed]

149. Polat, A.; Tunc, T.; Erdem, G.; Yerebasmaz, N.; Tas, A.; Beken, S.; Basbozkurt, G.; Saldir, M.; Zenciroglu, A.; Yaman, H.; et al. Interleukin-8 and its receptors in human milk from mothers of full-term and premature infants. Breastfeed. Med. 2016, 11, 247-251. [CrossRef] [PubMed] 
150. Aspinall, R.; Prentice, A.M.; Ngom, P.T. Interleukin 7 from maternal milk crosses the intestinal barrier and modulates T-cell development in offspring. PLoS ONE 2011, 6, e20812. [CrossRef] [PubMed]

151. Maheshwari, A.; Lu, W.; Lacson, A.; Barleycorn, A.A.; Nolan, S.; Christensen, R.D.; Calhoun, D.A. Effects of Interleukin-8 on the Developing Human Intestine. Cytokine 2002, 20, 256-267. [CrossRef] [PubMed]

152. Mehta, R.; Petrova, A. Very Preterm Gestation and Breastmilk Cytokine Content During the First Month of Lactation. Breastfeed. Med. 2011, 6, 21-24. [CrossRef] [PubMed]

153. Abdelhamid, A.E.; Chuang, S.L.; Hayes, P.; Fell, J.M.E. Evolution of in vitro cow's milk protein-specific inflammatory and regulatory cytokine responses in preterm infants with necrotising enterocolitis. Pediatr. Res. 2011, 69, 165-169. [CrossRef] [PubMed]

154. Branton, M.H.; Kopp, J.B. TGF-beta and fibrosis. Microbes Infect. 1999, 1, 1349-1365. [CrossRef]

155. Donnet-Hughes, A.; Duc, N.; Serrant, P.; Vidal, K.; Schiffrin, E. Bioactive molecules in milk and their role in health and disease: The role of transforming growth factor- $\beta$. Immunol. Cell Biol. 2000, 78, 74-79. [CrossRef] [PubMed]

156. Morita, Y.; Campos-Alberto, E.; Yamaide, F.; Nakano, T.; Ohnisi, H.; Kawamoto, M.; Kawamoto, N.; Matsui, E.; Kondo, N.; Kohno, Y.; et al. TGF- $\beta$ Concentration in Breast Milk is Associated with the Development of Eczema in Infants. Front. Pediatr. 2018, 6, 1-6. [CrossRef] [PubMed]

157. Iyengar, S.R.; Walker, W.A. Immune factors in breast milk and the development of atopic disease. J. Pediatr. Gastroenterol. Nutr. 2012, 55, 641-647. [CrossRef] [PubMed]

158. Rogier, E.W.; Frantz, A.L.; Bruno, M.E.C.; Wedlund, L.; Cohen, D.A.; Stromberg, A.J.; Kaetzel, C.S. Secretory antibodies in breast milk promote long-term intestinal homeostasis by regulating the gut microbiota and host gene expression. Proc. Natl. Acad. Sci. USA 2014, 111, 3074-3079. [CrossRef] [PubMed]

159. Reed, J.R.; Schwertfeger, K.L. Immune cell location and function during post-natal mammary gland development. J. Mammary Gland Biol. Neoplasia 2010, 15, 329-339. [CrossRef] [PubMed]

160. Ustundag, B.; Yilmaz, E.; Dogan, Y.; Akarsu, S.; Canatan, H.; Halifeoglu, I.; Cikim, G.; Denizmen Aygun, A. Levels of cytokines (IL-1 $\beta$, IL-2, IL-6, IL-8, TNF- $\alpha$ ) and trace elements $(\mathrm{Zn}, \mathrm{Cu})$ in breast milk from mothers of preterm and term infants. Med. Inflamm. 2005, 2005, 331-336. [CrossRef] [PubMed]

161. Hawkes, J.S.; Bryan, D.L.; James, M.J.; Gibson, R.A. Cytokines (IL-1 $\beta$, IL-6, TNF- $\alpha$, TGF- $\beta 1$, and TGF- $\beta 2$ ) and prostaglandin E2in human milk during the first three months postpartum. Pediatr. Res. 1999, 46, 194-199. [CrossRef] [PubMed]

162. Hrdý, J.; Novotná, O.; Kocourková, I.; Prokešová, L. Cytokine expression in the colostral cells of healthy and allergic mothers. Folia Microbiol. (Praha) 2012, 57, 215-219. [CrossRef]

163. Erbağci, A.B.; Çekmen, M.B.; Balat, Ö.; Balat, A.; Aksoy, F.; Tarakçioğlu, M. Persistency of high proinflammatory cytokine levels from colostrum to mature milk in preeclampsia. Clin. Biochem. 2005, 38, 712-716. [CrossRef]

164. Soto-Ramírez, N.; Boyd, K.; Zhang, H.; Gangur, V.; Goetzl, L.; Karmaus, W. Maternal serum but not breast milk IL-5, IL-6, and IL-13 immune markers are associated with scratching among infants. Allergy Asthma Clin. Immunol. 2016, 12, 399. [CrossRef]

165. Patki, S.; Kadam, S.; Chandra, V.; Bhonde, R. Human breast milk is a rich source of multipotent mesenchymal stem cells. Hum. Cell 2010, 23, 35-40. [CrossRef]

166. Molès, J.P.; Tuaillon, E.; Kankasa, C.; Bedin, A.S.; Nagot, N.; Marchant, A.; McDermid, J.M.; Van de Perre, P. Breastmilk cell trafficking induces microchimerism-mediated immune system maturation in the infant. Pediatr. Allergy Immunol. 2018, 29, 133-143. [CrossRef] [PubMed]

167. Cacho, N.T.; Lawrence, R.M. Innate immunity and breast milk. Front. Immunol. 2017, 8, 584. [CrossRef]

168. Järvinen, K.-M.; Soumalainen, H. Leucocytes in human milk and lymphocyte subsets in cow 's milk-allergic infants. Pediatr. Allergy Immunol. 2002, 13, 243-254. [CrossRef] [PubMed]

169. Vass, R.A.; Kemeny, A.; Dergez, T.; Ertl, T.; Reglodi, D.; Jungling, A.; Tamas, A. Distribution of bioactive factors in human milk samples. Int. Breastfeed. J. 2019, 14, 1-10. [CrossRef] [PubMed]

170. Bendiks, M.; Kopp, M.V. The relationship between advances in understanding the microbiome and the maturing hygiene hypothesis. Curr. Allergy Asthma Rep. 2013, 13, 487-494. [CrossRef] [PubMed]

171. Perez, P.F.; Dore, J.; Leclerc, M.; Levenez, F.; Benyacoub, J.; Serrant, P.; Segura-Roggero, I.; Schiffrin, E.J.; Donnet-Hughes, A. Bacterial Imprinting of the Neonatal Immune System: Lessons from Maternal Cells? Pediatrics 2007, 119, e724-e732. [CrossRef] 
172. Mcguire, M.K.; Mcguire, M.A. Human Milk: Mother Nature's Prototypical Probiotic Food? Adv. Nutr. 2015, 6, 112-123. [CrossRef] [PubMed]

173. Boix-Amorós, A.; Collado, M.C.; Mira, A. Relationship between milk microbiota, bacterial load, macronutrients, and human cells during lactation. Front. Microbiol. 2016, 7, 3389. [CrossRef]

174. Grönlund, M.; Gueimonde, M.; Laitinen, K.; Kociubinski, G.; Gronroos, T.; Salminen, S.; Isolauri, E. Maternal breast-milk and intestinal bifidobacteria guide the compositional development of the bifidobacterium microbiota in infants at risk of allergic disease. Clin. Exp. Allergy 2007, 37, 1764-1772. [CrossRef]

175. Martín, V.; Maldonado-Barragán, A.; Moles, L.; Rodriguez-Baños, M.; Del Campo, R.; Fernández, L.; Rodríguez, J.M.; Jiménez, E. Sharing of Bacterial Strains Between Breast Milk and Infant Feces. J. Hum. Lact. 2012, 28, 36-44. [CrossRef]

176. Gueimonde, M.; Sakata, S.; Kalliomäki, M.; Isolauri, E.; Benno, Y.; Salminen, S. Effect of maternal consumption of Lactobacillus GG on transfer and establishment of fecal bifidobacterial microbiota in neonates. J. Pediatr. Gastroenterol. Nutr. 2006, 42, 166-170. [CrossRef] [PubMed]

177. Barthow, C.; Wickens, K.; Stanley, T.; Mitchell, E.A.; Maude, R.; Abels, P.; Purdie, G.; Murphy, R.; Stone, P.; Kang, J.; et al. The Probiotics in Pregnancy Study (PiP Study): Rationale and design of a double-blind randomised controlled trial to improve maternal health during pregnancy and prevent infant eczema and allergy. BMC Pregnancy Childbirth 2016, 16, 1-14. [CrossRef] [PubMed]

178. Underwood, M.A.; Gaerlan, S.; De Leoz, M.L.A.; Dimapasoc, L.; Kalanetra, K.M.; Lemay, D.G.; German, J.B.; Mills, D.A.; Lebrilla, C.B. Human milk oligosaccharides in premature infants: Absorption, excretion, and influence on the intestinal microbiota. Pediatr. Res. 2015, 78, 670-677. [CrossRef] [PubMed]

(C) 2019 by the authors. Licensee MDPI, Basel, Switzerland. This article is an open access article distributed under the terms and conditions of the Creative Commons Attribution (CC BY) license (http://creativecommons.org/licenses/by/4.0/). 